\title{
Platinum(II) Compounds Containing Cyclometalated Tridentate Ligands: Synthesis, Luminescence Studies, and a Selective Fluoro for Methoxy Substitution
}

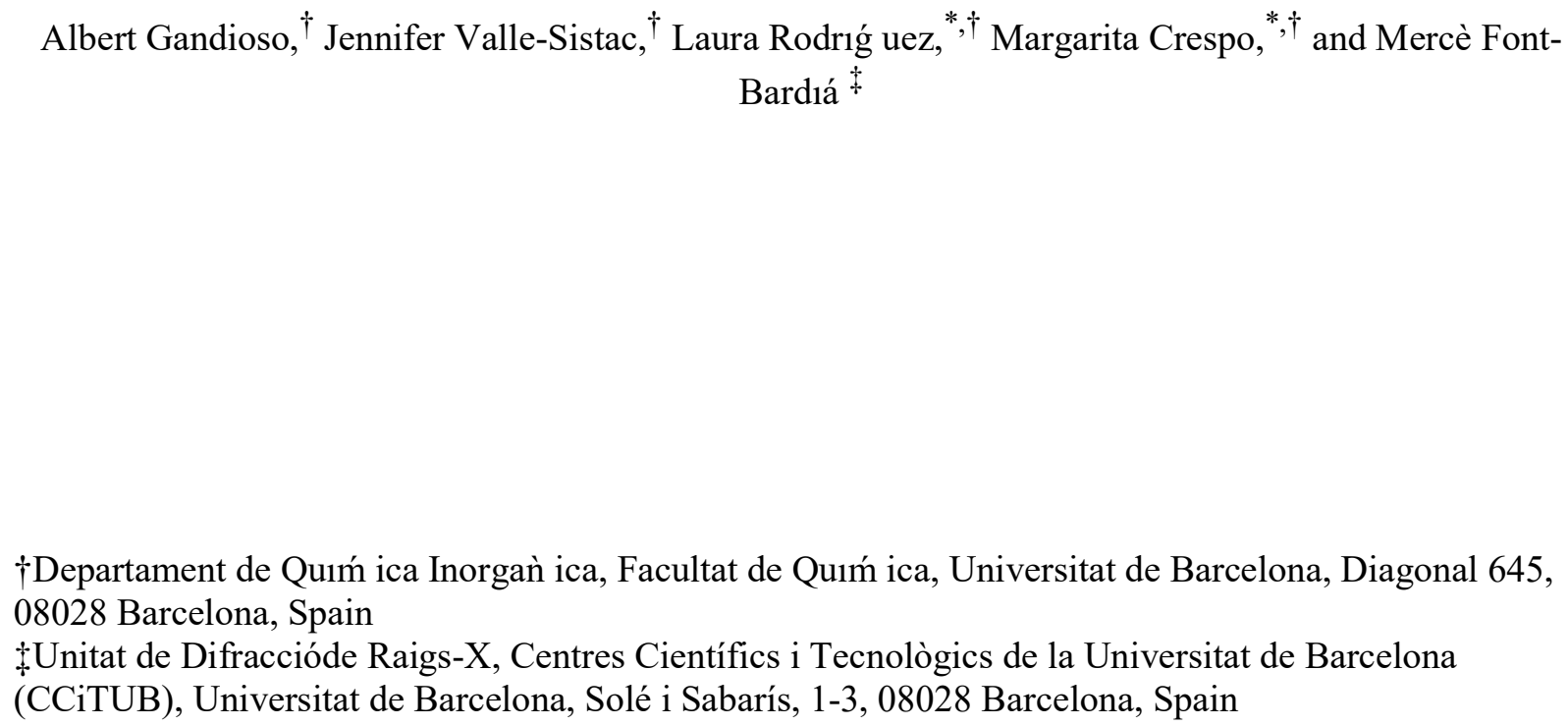


Two series of potentially tridentate ligands of formula $\mathrm{ArCH}=\mathrm{N}(\mathrm{CH} 2) 2 \mathrm{NMe} 2$ and $\mathrm{ArCH}=\mathrm{N}(\mathrm{CH} 2) 3 \mathrm{NMe} 2(\mathrm{Ar}=\mathrm{C} 6 \mathrm{H} 5,2-\mathrm{FC} 6 \mathrm{H} 4,4-\mathrm{FC} 6 \mathrm{H} 4,2,3,4-\mathrm{F} 3 \mathrm{C} 6 \mathrm{H} 2)$ were used to prepare $\left[\mathrm{C}, \mathrm{N}, \mathrm{N}^{\prime}\right]$-cyclometalated platinum compounds containing either a chloro or a methyl ancillary ligand. The synthesis of the compounds $[\mathrm{PtCl}\{\mathrm{Me} 2 \mathrm{~N}(\mathrm{CH} 2) \mathrm{xN}=\mathrm{CHR}\}](3 \mathrm{a}-\mathrm{h})$, via the corresponding compounds $[\mathrm{PtCl} 2\{\mathrm{Me} 2 \mathrm{~N}(\mathrm{CH} 2) \times \mathrm{N}=\mathrm{CHAr}\}](2)$, requires drastic conditions and proceeds more easily for ligands derived from $\mathrm{N}, \mathrm{N}$-dimethylpropylenediamine $(\mathrm{x}=3)$. Along the process, an unexpected selective nucleophilic substitution of a fluoro for a methoxy substituent took place at the aryl ring for ligands 2,3,4-F3C6H2CH=N(CH2)xNMe2. The syntheses of compounds $[\mathrm{PtMe}\{\mathrm{Me} 2 \mathrm{~N}(\mathrm{CH} 2) \mathrm{xN}=\mathrm{CHR}\}](4 \mathrm{a}-\mathrm{h})$ using $[\mathrm{Pt} 2 \mathrm{Me} 4(\mu-\mathrm{SMe} 2) 2]$ as a precursor took place for all ligands under relatively mild conditions. All compounds were fully characterized, including molecular structure determination for $[\mathrm{PtCl}\{\mathrm{Me} 2 \mathrm{~N}(\mathrm{CH} 2) 3 \mathrm{~N}=\mathrm{CH}(4-\mathrm{FC} 6 \mathrm{H} 3)\}](3 \mathrm{~b})$ and $[\mathrm{PtCl}\{\mathrm{Me} 2 \mathrm{~N}-$ $(\mathrm{CH} 2) 3 \mathrm{~N}=\mathrm{CH}(2-\mathrm{OMe}, 3,4-\mathrm{F} 2 \mathrm{C} 6 \mathrm{H})\}](3 \mathrm{~g})$. The absorption and emission spectra were also studied for the $\left[\mathrm{C}, \mathrm{N}, \mathrm{N}^{\prime}\right]$-cyclometalated platinum(II) compounds, and all of the compounds were emissive in the solid state and in dichloromethane solution at room temperature (compounds 3 ) or at $77 \mathrm{~K}$ (compounds 4 ). The size of the $\left[\mathrm{N}, \mathrm{N}^{\prime}\right]$-chelate ring and the number and position of the substituents in the aryl ring

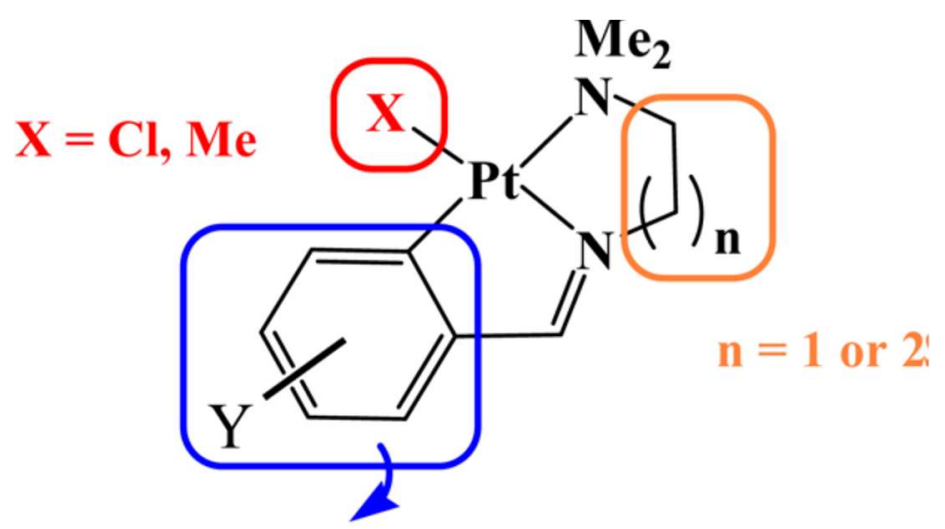




\section{INTRODUCTION}

59 In the last years significant research effort has focused on the photophysical properties of luminescent

60 square-planar platinum complexes. The aim of this research is to provide an understanding of the factors

61 that govern the luminescence efficiencies of platinum(II) complexes as well as to apply these

62 compounds in organic light emitting diodes (OLEDs) and in other devices.1

63 Many cyclometalated platinum complexes have proved to be luminescent in solution at ambient

64 temperature, because [C,N] ligands increase the energies of metal-centered excited states in comparison

65 to analogous $[\mathrm{N}, \mathrm{N}]$ ligands. 1 In addition, rigidity generally favors luminescence over nonradiative decay

66 pathways, and therefore tridentate $[\mathrm{N}, \mathrm{N}, \mathrm{C}],[\mathrm{N}, \mathrm{C}, \mathrm{N}]$, and $[\mathrm{C}, \mathrm{N}, \mathrm{C}]$ ligands generally based on substituted

67 pyridines and polypyridines may offer an advantage over bidentate [C,N] ligands.2 Moreover,

68 systematic studies carried out for several of these systems indicate that the emission may be tuned by

69 structural modification of the ligands; in particular, the nature and the position of the substituents might

70 influence the photophysics of the platinum complexes.1,3

71 In spite of the great number of cycloplatinated compounds for which the luminescence properties have

72 been studied so far, those containing aldimine or ketimine ligands have been less explored.4 In this work

73 we report the preparation and luminescence properties of cyclometalated platinum compounds

74 containing tridentate $\left[\mathrm{C}, \mathrm{N}, \mathrm{N}^{\prime}\right]$ imine ligands with fluoro substituents (compounds 3 and 4 shown in

75 Chart 1). This study should allow us to compare the behavior of these compounds in relation with (a) the

76 size of the $\left[\mathrm{N}, \mathrm{N}^{\prime}\right]$ chelate ring (five- versus six-membered), (b) the number and position of the fluoro

77 substituents in the ring, and (c) the nature of the ancillary ligands (methyl or chloro) coordinated to the

78 platinum. These effects will also be analyzed in relation to the choice and success of the preparation

79 procedure.

80 
84 Two series of potentially tridentate ligands of formula $\mathrm{ArCH}=\mathrm{N}(\mathrm{CH} 2) 2 \mathrm{NMe} 2$ and

dimethylethylenediamine and N,N-dimethylpropylenediamine, respectively, were used in the present work. As stated above, the ligands were selected in order to compare the results between those derived from propylene or ethylenediamine, as well as to analyze the effect of fluorine substituents. In particular, the position of a single fluoro substituent in an ortho or para position as well as the increased fluorination will be studied.

Synthesis of Compounds $[\mathrm{PtCl}\{\mathrm{Me} 2 \mathrm{~N}(\mathrm{CH} 2) \mathbf{X N}=\mathbf{C H R}\}](3 \mathrm{a}-\mathbf{h})$. The syntheses of compounds $[\mathrm{PtCl}\{\mathrm{Me} 2 \mathrm{~N}(\mathrm{CH} 2) 3 \mathrm{~N}=\mathrm{CHC} 6 \mathrm{H} 5\}](3 \mathrm{e}) 5$ and $[\mathrm{PtCl}\{\mathrm{Me} 2 \mathrm{~N}(\mathrm{CH} 2) 2 \mathrm{~N}=\mathrm{CHC} 6 \mathrm{H} 5\}]$ (3f)6 have been previously reported from the corresponding ligands, cis-[PtCl2(dmso)2] as metalating agent, methanol as solvent, and sodium acetate as an external base. However, a systematic comparison of the reactivities of both series of ligands containing either an ethylene or a propylene moiety linking the two nitrogen atoms and different substituents in the aryl ring has not been carried out so far. With this purpose, in this work we planned to follow the general synthetic procedure shown in Scheme 1 for both series of imines.

Initially, several reaction conditions were tested for ligand 1a, including either one-pot procedures or prior isolation of the corresponding $\left[\mathrm{N}, \mathrm{N}^{\prime}\right]$-chelate complex $2 \mathrm{a}$. As previously reported for similar systems, 5-7 the best results were obtained when [N, $\left.\mathrm{N}^{\prime}\right]$ coordination compounds (compounds 2 ) were previously isolated and such complexes, when refluxed for several hours in a donor solvent in the presence of sodium acetate, further reacted to yield cycloplatinated derivatives via $\mathrm{C}-\mathrm{H}$ activation. The best results for the latter step were obtained when an equivalent amount of sodium acetate was used and the reaction time in refluxing methanol was $48-72 \mathrm{~h}$, since the use of larger amounts of added base, prolonged reaction times, or the use of mixtures of toluene and methanol as solvents led to partial decomposition with formation of metallic platinum. Therefore, these optimal reaction conditions were followed in the synthesis of compounds 3 , which requires previous isolation of the corresponding compounds 2 .

The reaction of the imines $1 \mathrm{a}-\mathrm{g}$ with cis-[PtCl2 $(\mathrm{dmso}) 2]$ in refluxing methanol gave the corresponding coordination compounds [PtCl2 $\{\mathrm{Me} 2 \mathrm{~N}(\mathrm{CH} 2) \times \mathrm{N}=\mathrm{CHAr}\}]$ (2). For ligands derived from N,Ndimethylpropanediamine a mixture of two isomers corresponding to the two possible conformations ( $\mathrm{Z}$ and $\mathrm{E}$ ) around the $\mathrm{C}=\mathrm{N}$ bond was obtained. Generally, the $\mathrm{Z}$ isomer was the most abundant, or even the only one which was isolated and characterized, as for $2 \mathrm{~b}$. However, for ligands derived from N,Ndimethylethylenediamine, the corresponding coordination compounds were isolated exclusively as the less sterically crowded $\mathrm{E}$ isomer. The different behavior might arise from the higher flexibility of the six- versus the five-membered $\left[\mathrm{N}, \mathrm{N}^{\prime}\right]$-chelate rings, which minimizes the steric crowding around the platinum in the $\mathrm{Z}$ isomer. As previously reported,5,8 these isomers display striking differences in their spectral features. In particular, the imine proton of the $\mathrm{E}$ isomers is strongly deshielded $(\delta \mathrm{ca} .9 .30-9.60$ $\mathrm{ppm})$ due to the proximity to platinum and displays lower $\mathrm{J}(\mathrm{H}-\mathrm{Pt})$ values $(48-60 \mathrm{~Hz})$ in comparison to those for the $\mathrm{Z}$ isomers $(115-120 \mathrm{~Hz}$ ). In addition, for the $\mathrm{Z}$ isomer both the methylene and $\mathrm{NMe} 2$ protons are nonequivalent. The number of signals observed in the 19F NMR spectra was in all cases consistent with the presence of one or two isomers, as well as with the number of fluorine substituents in the imine. Formation of the $\left[\mathrm{N}, \mathrm{N}^{\prime}\right]$-chelate compounds $[\mathrm{PtCl}\{\mathrm{Me} 2 \mathrm{~N}(\mathrm{CH} 2) \mathrm{xN}=\mathrm{CHAr}\}]$ (2) was confirmed by $\operatorname{ESI}(+)$ mass spectra and elemental analyses.

The tridentate $\left[\mathrm{C}, \mathrm{N}, \mathrm{N}^{\prime}\right]$ cyclometalated compounds $3 \mathrm{a}-\mathrm{d}$ were obtained from the equimolar reaction of the coordination compounds and sodium acetate in refluxing methanol. The process involves the activation of a $\mathrm{C}(\operatorname{aryl})-\mathrm{H}$ bond and the formal release of $\mathrm{HCl}$, which is promoted in the presence of a 
an unreactive $\mathrm{E}$ to the adequate $\mathrm{Z}$ conformation. In contrast, compounds $2 \mathrm{a}, \mathrm{b}$, containing the more flexible propylene moiety, were obtained as a mixture of $Z$ and $E$ conformers (2a) or as the $Z$ conformer exclusively (2b), thus facilitating the cyclometalation process. The yields of the cyclometalation reactions were in all cases moderate; however, slightly higher yields in the range $36-40 \%$ were obtained for propylene derivatives $3 \mathrm{a}, \mathrm{b}$ after $48 \mathrm{~h}$ in comparison to those for the corresponding ethylene derivatives $3 \mathrm{c}, \mathrm{d}$, for which yields in the range $29-32 \%$ were obtained after $72 \mathrm{~h}$. These results confirm that the higher flexibility of the propylene versus the ethylene moieties facilitates the cyclometalation reaction, leading to $\left[\mathrm{C}, \mathrm{N}, \mathrm{N}^{\prime}\right]$-cycloplatinated compounds. In all cases, $1 \mathrm{H}$ NMR spectra confirmed the formation of the expected fused $[6,5,6]$ - or $[6,5,5]$-tricyclic system. As reported for analogous systems, 5,6,8 $\mathrm{J}(\mathrm{H}-\mathrm{Pt})$ values for the imine proton $(141-144 \mathrm{~Hz})$ are higher than those observed for compounds 2 . The 19F NMR spectra show only one signal, for which coupling to platinum was only observed for compound 3a. For 3b, 13C NMR and 1H-13C-HSQC spectra were also taken and confirm the cyclometalation process, since only three resonances corresponding to aromatic $\mathrm{C}-\mathrm{H}$ were observed. All compounds were characterized by $\operatorname{ESI}(+)$ mass spectra and elemental analyses, and $3 \mathrm{~b}$ was also characterized crystallographically.

With the aim of obtaining the corresponding tridentate $\left[\mathrm{C}, \mathrm{N}, \mathrm{N}^{\prime}\right]$-cyclometalated compounds the reactions of the coordination compounds $2 \mathrm{~g}$,h with an equimolar amount of sodium acetate in refluxing methanol were also carried out. However, for these ligands the reaction (shown in Scheme 2) was more complex and involved a selective nucleophilic substitution of the fluorine substituent adjacent to the imine group for a methoxy group, leading eventually to the compounds $[\mathrm{PtCl}\{\mathrm{Me} 2 \mathrm{~N}(\mathrm{CH} 2) \mathrm{xN}=\mathrm{CH}(2-$ $\mathrm{OMe}, 3,4-\mathrm{F} 2 \mathrm{C} 6 \mathrm{H})\}](3 \mathrm{~g}$ for $\mathrm{x}=3$ and $3 \mathrm{~h}$ for $\mathrm{x}=2)$. Selective platinum-catalyzed activation and subsequent functionalization of aryl $\mathrm{C}-\mathrm{F}$ bonds to produce arylmethyl ethers in a process involving platinum(IV)/platinum(II) species has been reported. 9 The involvement of platinum(IV) species is ruled out in the present case, since previous results indicate that intramolecular $\mathrm{C}-\mathrm{F}$ bond activation takes place at electron-rich platinum substrates such as [Pt2Me4( $\mu-\mathrm{SMe} 2) 2]$ but not at cis- $[\mathrm{PtCl} 2(\mathrm{dmso}) 2] .10$ On the other hand, ligands $1 \mathrm{~g}$, h were recovered unaltered after $72 \mathrm{~h}$ of reflux in methanol in the presence of an equimolar amount of sodium acetate. Moreover, the fluoro for methoxy substitution was not observed along the syntheses of compounds $3 \mathrm{a}-\mathrm{d}$, for which only one fluoro substituent is present. Therefore, it is likely that the combined effects of coordination of the imine ligand to platinum and the presence of several fluorine substituents are able to activate the fluoroaryl group toward nucleophilic aromatic substitution in a way similar to that for recently reported examples in which acetylenes are used as electron-withdrawing groups promoting nucleophilic aromatic substitution. 11 The presence of sodium acetate in the reaction media is also required, since the fluoro for methoxy substitution process was not observed in the preparation of compounds $2 \mathrm{~g}$,h. It is interesting to point out that fluorine for alkoxy nucleophilic substitution has been reported as a strategy leading to blue-emitting cyclometalated iridium(III) complexes with increased solubility. 12

In both cases, the $1 \mathrm{H}$ NMR spectra confirmed formation of the [C,N,N']-cycloplatinated compounds and the $\mathrm{J}(\mathrm{H}-\mathrm{Pt})$ values for the imine proton are similar to those obtained for compounds $3 \mathrm{a}-\mathrm{d}$. Only one resonance corresponding to an aromatic proton was observed, and a doublet at ca. $4 \mathrm{ppm}$ was assigned to the methoxy hydrogen atoms which are coupled to the adjacent fluorine. The 19F NMR spectra show only two signals, whose multiplicities and coupling constants are in good agreement with the proposed structures. 13 The characterization of these compounds was completed with ESI $(+)$ mass spectra, elemental analyses, and the determination of the molecular structure of $3 \mathrm{~g}$.

Crystal Structures of Compounds 3b,g. Suitable crystals of compounds 3b,g (Figures 1 and 2, respectively) were grown from dichloromethane-methanol solution. For $3 \mathrm{~b}$, the asymmetric unit contains eight molecules (Figures S1 and S2, Supporting Information) that are spaced between 5 and 8 $\AA$ : i.e., the distances are too long to be able to establish weak intermolecular interactions. The crystal structure of $3 \mathrm{~g}$ is constituted by two different molecules distributed in antiparallel positions (Figure S3, Supporting Information) which are connected by $\mathrm{H}$ bonds between the $\mathrm{O}$ atom of the methoxy units and 
one hydrogen atom of the central methylene of the diamine of a second molecule. The 3D packing of the complex is constituted by different dimers, as shown in the unit cell (Figure S4, Supporting Information).

The compounds consist of a fused [6,5,6]-tricyclic system containing an ortho-metalated phenyl group, a five-membered metallacycle and a six-membered chelate ring with two nitrogen atoms coordinated to platinum. The square-planar coordination around the platinum is completed with a chlorine atom. For $3 \mathrm{~g}$, the molecular structure provides conclusive evidence of the presence of a methoxy group in the position adjacent to the imine moiety, as deduced from NMR spectra. Bond lengths and angles are well within the range of values obtained for analogous compounds.5-8 The Pt-amine distances are greater than Pt-imine distances in agreement with both the weaker ligating ability of amines for platinum and the greater trans influence of the aryl versus the chloro ligand.8c Most bond angles at platinum are close to the ideal value of $90^{\circ}$, and the smallest angle corresponds in each case to the metallacycle $\left(80.3(4)^{\circ}\right.$ $(3 \mathrm{~b})$ and $\left.80.76(15)^{\circ}(3 \mathrm{~g})\right)$. As previously observed for related compounds, 5 the six-membered chelate ring presents a strong deviation from planarity and the chelate angles $\mathrm{N}(1)-\mathrm{Pt}-\mathrm{N}(2)\left(97.2(4)^{\circ}(3 \mathrm{~b})\right.$ and $\left.96.78(13)^{\circ}(3 \mathrm{~g})\right)$ are in both cases greater than for analogous compounds with a fivemembered chelate ring. In each case, the metallacycle is nearly coplanar with the coordination plane, the dihedral angle between the mean planes being $2.3(4)^{\circ}$ for $3 \mathrm{~b}$ and $3.22(15)^{\circ}$ for $3 \mathrm{~g}$.

Synthesis of Compounds [PtMe $\{\mathrm{Me} 2 \mathrm{~N}(\mathrm{CH} 2) \times \mathbf{N C H}=\mathbf{R}\}](4 \mathbf{a}-\mathbf{h})$. The synthesis of compounds $[\mathrm{PtMe}\{\mathrm{Me} 2 \mathrm{~N}-(\mathrm{CH} 2) \mathrm{xN}=\mathrm{CHR}\}](4 \mathrm{a}-\mathrm{h})$ was carried out following the previously reported procedures for compounds $4 \mathrm{c}, \mathrm{f}, \mathrm{h}$, which consist of the reaction of [Pt2Me4( $\mu$-SMe2)2] with the corresponding imine.14 The mechanism of these reactions has been thoroughly studied, and it is assumed that prior coordination of the ligand produces $\left[\mathrm{N}, \mathrm{N}^{\prime}\right]$-chelate complexes that further react to produce cyclometalated compounds with loss of methane.14 These compounds have been generally prepared under mild conditions, for instance in acetone at room temperature, and the bidentate imines used so far are derived from N,N-dimethylethylenediamines. In this work, as shown in Scheme 3, the reactions were carried out in refluxing toluene and were completed within $1 \mathrm{~h}$ for both imines derived from ethylene and propylenediamines. In this case, no further reaction was observed for the trifluorinated imines $1 \mathrm{~g}, \mathrm{~h}$, which can be related to the greater electron density of the platinum in these compounds, as well as to the absence of methanol in the reaction mixtures. As a whole, this method appear to be a convenient one-pot procedure that does not require previous isolation of the corresponding coordination compounds to give the cyclometalated compounds with good yields. In all cases, $1 \mathrm{H}$ NMR spectra confirmed formation of the expected $\left[\mathrm{C}, \mathrm{N}, \mathrm{N}^{\prime}\right]$ cycloplatinated compounds, in which a methyl ligand completes the coordination sphere around the platinum. The methyl ligand, the imine, and the NMe2 are coupled to platinum, and the $\mathrm{J}(\mathrm{H}-\mathrm{Pt})$ values for the imine proton $(\mathrm{ca} .60 \mathrm{~Hz})$ are lower than those obtained for compounds 3 , which is consistent with the presence of a methyl instead of a chloro ligand trans to the imine.8a,b The 19F NMR spectra are consistent with the proposed structures: in particular, the presence of three signals for $4 \mathrm{~g}, \mathrm{~h}$ confirms the presence of the three fluoro atoms.
Absorption and Emission Spectroscopy. Both absorption and emission spectra have been recorded in aerated dichloromethane solutions, and emission spectra were also recorded in the solid state for cyclometalated platinum compounds 3 and 4 . The resulting data are shown in Table 1 with representative absorption and emission spectra shown in Figures 3-6.

The absorption spectra of 10-4 M dichloromethane solution of compounds 3 in solution at $298 \mathrm{~K}$ show several bands in the UV-visible range with moderate $\varepsilon$ values. The lowest energy band in the range $376-400 \mathrm{~nm}$ with extinction coefficients between 2200 and $5100 \mathrm{M}-1 \mathrm{~cm}-1$ is attributable to $\mathrm{Pt}(5 \mathrm{~d}) \rightarrow$ $\pi^{*}(\mathrm{~L})$ metal-to-ligand charge transfer (MLCT) mixed with intraligand (IL) transitions. 15 Compounds 3 emit in the visible region at $298 \mathrm{~K}$ when excited at the wavelength corresponding in each case to the lowest energy band. The emission spectra of all compounds 3 follow a similar pattern and display three maxima (one displayed as shoulder) in the range $575-700 \mathrm{~nm}$. The observation of vibronically 
structured bands with progressional spacings at ca. $1200 \mathrm{~cm}-1$, typical of $v(C=C)$ and $v(C=N)$ stretching

frequencies in the excited state, demonstrates the involvement of ligand character in their emission origin. Solid emission spectra were also recorded upon excitation of the samples at the corresponding lowest energy absorption band. In all cases, the same profile (well vibronically structured band) as recorded in solution is observed (Table 1 and Figures S5 and S6 (Supporting Information)). No excimeric emission bands that usually present broad emission bands were recorded in any case. Emission spectra were also recorded at different concentrations in order to check if possible aggregate formation was obtained in solution. As can be seen in Figure S8 (Supporting Information), the emission profile when going from $1 \times 10^{-4}$ to $3 \times 10^{-5} \mathrm{M}$ is similar and the contribution of aggregates on the spectra does not seem to be very certain. Nevertheless, it cannot be ruled out definitively, due to the small increase of the longer wavelength emission at higher concentrations. This is in agreement with the fact that no $\pi-\pi$ stacking interactions are observed in the crystal packing of the molecules (Figures S1-S4, Supporting Information).

In all cases, the excitation spectra match the absorption spectra in solution at room temperature. The large red shift observed for the emission is characteristic of phosphorescence emission, as expected from a triplet state typical for platinum complexes due to strong spin-orbit coupling favored by the wellknown heavy-atom effect. This is in agreement with the high luminescence lifetime values estimated on the order of $1 \mu \mathrm{s}$ when we record the spectra of the complexes in the presence and in the absence of oxygen.

Although the differences in emission energies are very small, it was found that the presence of a fluoro substituent in position 2 produces a small red shift (ca. $5 \mathrm{~nm}$ ) and a blue shift $(10-15 \mathrm{~nm})$ for the substituent in position 4 for both series of compounds derived from ethylenediamine $(3 \mathrm{f}, \mathrm{c}, \mathrm{d})$ or from propylenediamine $(3 \mathrm{e}, \mathrm{a}, \mathrm{b})$. The apparently controversial effect of fluoro substituents can be rationalized by taking into account the inductive electron-withdrawing and the mesomeric electron-donating effects of fluorine, which might result in an decreased or an increased electron density on platinum. 3 Compounds $3 \mathrm{~g}$,h, which contain a methoxy group at the 2-position together with fluoro substituents at the 3- and 4-positions, also display a small red shift in comparison with the unsubstituted analogues $3 \mathrm{e}$,f. Similar effects in the emission wavelengths due to the presence of fluoro or methoxy substituents have been previously reported.3,16

The calculated quantum yields are modest (ca. 10-3) and are in agreement with the fact that the strongest emission is recorded for $3 \mathrm{~d}$. For each pair of compounds with the same substituents, the emission is more intense for the compounds derived from ethylenediamine than for those derived from propylenediamine $(3 c>3 a, 3 d>3 b, 3 f>3 e$, and $3 h>3 g)$. Although the differences are small, this trend is consistent with the fact that the greater rigidity associated with the five- versus the six-membered chelates favors luminescence over nonradiative decay pathways. Attempts to improve the photophysical properties by modifying the $[\mathrm{N}, \mathrm{C}, \mathrm{N}]$ ligand, in particular the size of the chelate rings, have been recently reported.17

Studies carried out for compounds 4 indicate absorption spectra similar to those obtained for compounds 3 , with the lowest energy band in the range 391-415 nm. The lower energy of these bands in comparison to those of compounds 3 (in the range 376-400 nm) can be related to the higher electron density at the metal center expected for compounds 4 . Compounds 4 , when excited at the lowest energy absorption band were nearly nonemissive in solution at room temperature. This could be due to the presence of a high-energy oscillator $(\mathrm{C}-\mathrm{H})$ in their first coordination sphere, which could provide an efficient pathway for multiphonon relaxation. On the other hand, at $77 \mathrm{~K}$ deactivation processes are minimized and emission was observed. The obtained spectra were similar to those corresponding to compounds 3. In particular, for both series of ligands derived from either ethylene or propylenediamine, a small red shift is observed when a fluoro substituent is present in position 2 ( $4 \mathrm{c}$ versus $4 \mathrm{f}$ or $4 \mathrm{a}$ versus $4 \mathrm{e}$ ), while the presence of a fluoro substituent in position 4 produces a small blue shift ( $4 \mathrm{~d}$ versus $4 \mathrm{f}$ or 
$2744 \mathrm{~b}$ versus $4 \mathrm{e}$ ). The most strongly emissive compound of this series is $4 \mathrm{~b}$, as shown in Figure 6 , where 275 the emission spectra of the complexes are normalized with respect to $4 \mathrm{~b}$.

276 Finally, a comparison of compounds 3 and 4 which only differ in the ancillary ligand (chloro versus 277 methyl) suggests that the chloro derivatives are best suited for photophysical properties, since they are 278 luminescent in solution at room temperature while methyl analogues only display this behaviour at low 279 temperature. This result supports the fact that the identity of the remaining ligand in tridentate 280 cycloplatinated compounds is also crucial in determining whether or not the compounds are emissive. $1 \mathrm{~b}$ 281 Although C-donor ligands such as cyanide and acetylide which are able to increase the ligand field 282 strength have been shown to give good results, $1 \mathrm{~b}$ the methyl ligand is not such a good choice since, as 283 stated above, it can provide an efficient pathway for multiphonon relaxation. 
289 The cyclometalated compounds [PtMe $\{\mathrm{Me} 2 \mathrm{~N}(\mathrm{CH} 2) \mathrm{xN}=\mathrm{CHR}\}](4 \mathrm{a}-\mathrm{h})$ with $\mathrm{R}=\mathrm{C} 6 \mathrm{H} 4,2-\mathrm{FC} 6 \mathrm{H} 3$, 4-

290 FC6H3, 2,3,4-F3C6H were easily obtained from the reaction of [Pt2Me4( $\mu$-SMe2)2] with the

291 corresponding ligands derived from either N,N-dimethylpropylene or N,N-dimethylethylenediamine. In

292 contrast, the synthesis of the corresponding chloro analogues $[\mathrm{PtCl}\{\mathrm{Me} 2 \mathrm{~N}(\mathrm{CH} 2) \times \mathrm{N}=\mathrm{CHR}\}](3 \mathrm{a}-\mathrm{h})$,

293 carried out from the corresponding precursors [ $\mathrm{PtCl} 2\{\mathrm{Me} 2 \mathrm{~N}(\mathrm{CH} 2) \mathrm{xN}=\mathrm{CHAr}\}](2)$, was found to be

294 more favored for six-membered than for five-membered [N, $\left.\mathrm{N}^{\prime}\right]$-chelates. This result is related to the fact

295 that for the latter the bidentate ligand adopts the $\mathrm{E}$ conformation and consequently an $\mathrm{E}-\mathrm{Z}$ isomerization

296 should precede the cyclometalation step. In addition, for the ligands 2,3,4-F3C6H2CHN(CH2)xNMe2

297 an unexpected nucleophilic substitution of a fluoro for a methoxy substituent took place along the

298 cyclometalation process, leading to the compounds $[\mathrm{PtCl}\{\mathrm{Me} 2 \mathrm{~N}(\mathrm{CH} 2) \mathrm{xN}=\mathrm{CH}(2-\mathrm{OMe}, 3,4-\mathrm{F} 2 \mathrm{C} 6 \mathrm{H})\}]$

299 ( $3 \mathrm{~g}$ for $\mathrm{x}=3$ and $3 \mathrm{~h}$ for $\mathrm{x}=2$ ). Further work aimed at analyzing the scope of this process is currently in

300 progress.

301 Cycloplatinated compounds $3 \mathrm{a}-\mathrm{g}$ are luminescent in the solid state and in solution at room temperature, 302 and those containing a [6,5,5]-tricyclic system display higher quantum yields in comparison to those 303 containing a $[6,5,6]$-tricyclic system. Cycloplatinated compounds $4 \mathrm{a}-\mathrm{g}$ are luminescent in the solid state 304 and in solution at low temperature. For both series of cyclometalated platinum compounds, the emission energies can be tuned by varying the aryl substituents. 
General Considerations. Microanalyses were performed at the Centres Cientifí cs i Tecnolog ics (Universitat de Barcelona).18 Mass spectra were performed at the Unitat d'Espectrometria de Masses (Universitat de Barcelona) in a LC/MSD-TOF spectrometer using 1/1 H2O/CH3CN to introduce the sample (ESI-MS) or in a ThermoFinnigan TRACE DSQ spectrometer (CI-MS). NMR spectra were performed at the Unitat de RMN d'Alt Camp de la Universitat de Barcelona using a Mercury-400 $(1 \mathrm{H}$, $400 \mathrm{MHz}$; 1H-13C HSQC; 13C, 100.6 MHz; 19F, 376.5 MHz) spectrometer and referenced to SiMe4 $(1 \mathrm{H}, 13 \mathrm{C})$ or $\mathrm{CFCl} 3(19 \mathrm{~F}) . \delta$ values are given in ppm and $\mathrm{J}$ values in $\mathrm{Hz}$. Abbreviations used: s, singlet; $\mathrm{d}$, doublet; t, triplet; q, quadruplet; qi, quintuplet; m, multiplet; br, broad. UV-visible spectra of $\mathrm{CH} 2 \mathrm{Cl} 2$ solutions of compounds 1, 3, and 4 were recorded at $298 \mathrm{~K}$ with a Cary 100 scan 388 Varian UV spectrometer, and the emission and excitation spectra of aerated solutions of compounds $3 \mathrm{a}-\mathrm{h}$ and $4 \mathrm{a}-\mathrm{h}$ were obtained on a Horiba Jobin-Yvon SPEX Nanolog-TM spectrofluorimeter at $298 \mathrm{~K}$ or at $77 \mathrm{~K}$. Deoxygenated solutions of the compounds have been also used for the estimation of luminescence lifetimes. This experiments have been done bubbling N2(g) previously saturated with dichloromethane in order to minimize the concentration of the sample. Total luminescence quantum yields were measured at $298 \mathrm{~K}$ relative to $[\mathrm{Ru}$ (bipy)3]Cl2 in water $(\phi=0.042)$ as a standard reference. 19 The corresponding absorption of the complexes used for these measurements is lower than 0.1 .

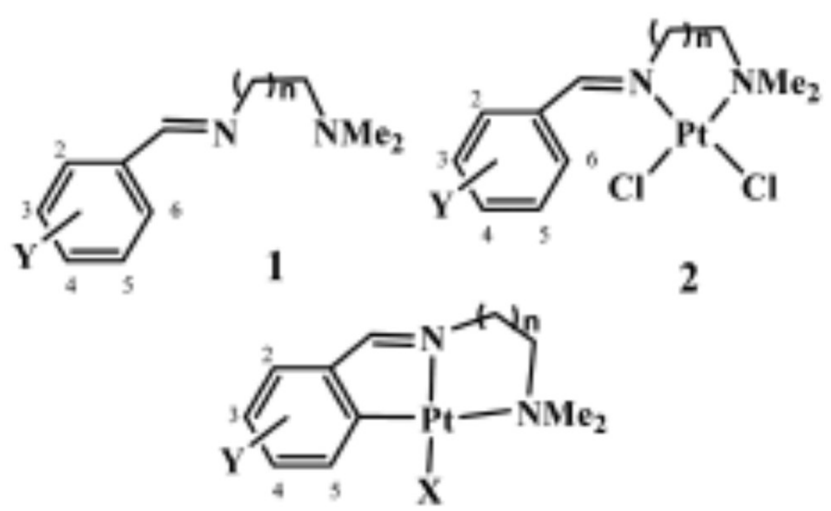

3 and 4

Preparation of the Complexes. The compounds cis-[PtCl2(dmso)2]20 and [Pt2Me4( $\mu-\mathrm{SMe} 2) 2], 21$ elsewhere. mmol) of 3-dimethylamino-1-propanamine with $0.610 \mathrm{~g}(4.9 \mathrm{mmol})$ of 2-fluorobenzaldehyde in $20 \mathrm{~mL}$ of toluene. The reaction mixture was stirred at room temperature for $2 \mathrm{~h}$, sodium sulfate was added and filtered off, and the solvent was removed under vacuum to give a yellow oil. Yield: $0.969 \mathrm{~g}(95 \%) .1 \mathrm{H}$ $\operatorname{NMR}(400 \mathrm{MHz}, \mathrm{CDCl} 3): \delta 8.25[\mathrm{~s}, 1 \mathrm{H}, \mathrm{CHN}] ; 7.96[\mathrm{dd}, 1 \mathrm{H}, 3 \mathrm{~J}(\mathrm{H}-\mathrm{H})=2.0,3 \mathrm{~J}(\mathrm{H}-\mathrm{H})=7.6, \mathrm{H} 6] ; 7.38$ $[\mathrm{m}, 1 \mathrm{H}, \mathrm{H} 5] ; 7.17[\mathrm{t}, 1 \mathrm{H}, 3 \mathrm{~J}(\mathrm{H}-\mathrm{H})=7.6, \mathrm{H} 4] ; 7.07[\mathrm{ddd}, 1 \mathrm{H}, 4 \mathrm{~J}(\mathrm{H}-\mathrm{H})=1.2,3 \mathrm{~J}(\mathrm{H}-\mathrm{H})=8.4,3 \mathrm{~J}(\mathrm{~F}-\mathrm{H})=$ $10.4, \mathrm{H} 3] ; 3.68[\mathrm{td}, 2 \mathrm{H}, 4 \mathrm{~J}(\mathrm{H}-\mathrm{H})=1.6,3 \mathrm{~J}(\mathrm{H}-\mathrm{H})=7.2, \mathrm{NCH} 2] ; 2.37[\mathrm{t}, 2 \mathrm{H}, 3 \mathrm{~J}(\mathrm{H}-\mathrm{H})=7.2$, 
4-FC6 $44 \mathrm{CH}=\mathrm{N}(\mathrm{CH} 2) 3 \mathrm{NMe} 2(1 \mathrm{~b})$. This compound was prepared as a yellow oil by following the same method from $0.510 \mathrm{~g}(5.0 \mathrm{mmol})$ of 3-dimethylamino-1-propanamine and $0.620 \mathrm{~g}(5.0 \mathrm{mmol})$ of 4fluorobenzaldehyde. Yield: $0.912 \mathrm{~g}(88 \%)$. 1H NMR (400 MHz, CDCl3): $\delta 8.25$ [s, 1H, CHN]; 7.72 [m, $2 \mathrm{H}, \mathrm{H} 2,6] ; 7.09[\mathrm{dd}, 2 \mathrm{H}, 4 \mathrm{~J}(\mathrm{H}-\mathrm{H})=2.4,3 \mathrm{~J}(\mathrm{~F}-\mathrm{H})=8.8, \mathrm{H} 3,5] ; 3.63[\mathrm{td}, 2 \mathrm{H}, 4 \mathrm{~J}(\mathrm{H}-\mathrm{H})=1.2,3 \mathrm{~J}(\mathrm{H}-\mathrm{H})=$ $7.2, \mathrm{NCH} 2] ; 2.36[\mathrm{t}, 2 \mathrm{H}, 3 \mathrm{~J}(\mathrm{H}-\mathrm{H})=7.2, \mathrm{CH} 2 \mathrm{NMe} 2] ; 2.24[\mathrm{~s}, 6 \mathrm{H}, \mathrm{NMe} 2] ; 1.87$ [qi, $2 \mathrm{H}, 3 \mathrm{~J}(\mathrm{H}-\mathrm{H})=7.2$, CH2CH2CH2]. 19F NMR (376.5 MHz, CDCl3): $\delta-109.92$ [m, 1F]. CI-MS: $208.9[\mathrm{M}+\mathrm{H}]+$.

4-FC6 $44 \mathrm{CH}=\mathrm{N}(\mathrm{CH} 2) 2 \mathrm{NMe} 2(1 \mathrm{~d})$. This compound was prepared as a pale yellow oil by following the same method from $0.580 \mathrm{~g}(6.3 \mathrm{mmol})$ of 2-dimethylamino-1-ethanamine and $0.880 \mathrm{~g}(7.1 \mathrm{mmol})$ of 4fluorobenzaldehyde. Yield: $1.119 \mathrm{~g}(92 \%)$. $1 \mathrm{H} \mathrm{NMR}(400 \mathrm{MHz}, \mathrm{CDCl} 3): \delta 8.26$ [s, 1H, CHN]; 7.71 $[\mathrm{dd}, 2 \mathrm{H}, 4 \mathrm{~J}(\mathrm{~F}-\mathrm{H})=5.6,3 \mathrm{~J}(\mathrm{H}-\mathrm{H})=8.8, \mathrm{H} 2,6] ; 7.06[\mathrm{t}, 2 \mathrm{H}, 3 \mathrm{~J}(\mathrm{H}-\mathrm{F})=3 \mathrm{~J}(\mathrm{H}-\mathrm{H})=8.8, \mathrm{H} 3,5] ; 3.71[\mathrm{t}$, $2 \mathrm{H}, 3 \mathrm{~J}(\mathrm{H}-\mathrm{H})=6.8, \mathrm{NCH} 2] ; 2.62[\mathrm{t}, 2 \mathrm{H}, 3 \mathrm{~J}(\mathrm{H}-\mathrm{H})=6.8, \mathrm{CH} 2 \mathrm{NMe} 2] ; 2.30$ [s, 6H, NMe2]. 19F NMR (376,5 MHz, CDCl3): $\delta-109.79$ [m, 1F]. CI-MS: $194.9[\mathrm{M}+\mathrm{H}]+$.

2,3,4-F3C6H2CH=N(CH2)3NMe2 (1g). This compound was prepared as a yellow oil following the same method from $0.638 \mathrm{~g}(6.24 \mathrm{mmol})$ of 3-dimethylamino-1-propanamine and $1.0 \mathrm{~g}(6.24 \mathrm{mmol})$ of 2,3,4-trifluorobenzaldehyde. Yield: $0.838 \mathrm{~g}(55 \%)$. $1 \mathrm{H} \mathrm{NMR}$ (400 MHz, CDCl3): $\delta 8.49$ [s, 1H, CHN]; $7.71[\mathrm{dd}, 1 \mathrm{H}, 3 \mathrm{~J}(\mathrm{H}-\mathrm{H})=8.0,4 \mathrm{~J}(\mathrm{H}-\mathrm{F})=4.0, \mathrm{H} 6] ; 7.01[\mathrm{~m}, 1 \mathrm{H}, \mathrm{H} 5] ; 3.67[\mathrm{t}, 2 \mathrm{H}, 3 \mathrm{~J}(\mathrm{H}-\mathrm{H})=6.8$, $\mathrm{NCH} 2] ; 2.34$ [t, 2H, 3J $(\mathrm{H}-\mathrm{H})=7.2, \mathrm{CH} 2 \mathrm{NMe} 2] ; 2.24$ [s, 6H, NMe2]; 1.86 [qi, 2H, 3J $(\mathrm{H}-\mathrm{H})=7.2$, $\mathrm{CH} 2 \mathrm{CH} 2 \mathrm{CH} 2$ ]. 19F NMR (376,5 MHz, CDCl3): $\delta-131.08$ [m, F2]; - 143.07 [dtd, 3J(F-F) = 18.8, $4 \mathrm{~J}(\mathrm{~F}-\mathrm{F})=3 \mathrm{~J}(\mathrm{H}-\mathrm{F})=7.5,4 \mathrm{~J}(\mathrm{~F}-\mathrm{H})=3.8, \mathrm{~F} 4] ;-160.90[\mathrm{tdd}, 3 \mathrm{~J}(\mathrm{~F}-\mathrm{F})=18.8,4 \mathrm{~J}(\mathrm{~F}-\mathrm{H})=7.5,5 \mathrm{~J}(\mathrm{~F}-\mathrm{H})=$ 2.2, F3]. CI-MS: $244.7[\mathrm{M}+\mathrm{H}]+$.

$[\mathrm{PtCl} 2\{\mathrm{Me} 2 \mathrm{~N}(\mathrm{CH} 2) 3 \mathrm{~N}=\mathrm{CH}(2-\mathrm{FC} 6 \mathrm{H} 4)\}]$ (2a). A mixture formed by $0.303 \mathrm{~g}(0.72 \mathrm{mmol})$ of cis[PtCl2(dmso)2] and $0.153 \mathrm{~g}(0.73 \mathrm{mmol})$ of imine 1a was treated with dry methanol and heated at $65^{\circ} \mathrm{C}$ for $4 \mathrm{~h}$ with continuous stirring. The mixture was filtered; the solvent was evaporated to half volume, allowing crystallization at room temperature. Yield (white solid; mixture of $\mathrm{E}$ and $\mathrm{Z}$ isomers): $0.223 \mathrm{~g}$ (65\%). 1H NMR (400 MHz, CDCl3): $\mathrm{Z}$ isomer $\delta 10.96[\mathrm{t}, 1 \mathrm{H}, 3 \mathrm{~J}(\mathrm{H}-\mathrm{H})=8.0, \mathrm{H} 6] ; 8.89[\mathrm{~s}, 1 \mathrm{H}$, $3 \mathrm{~J}(\mathrm{Pt}-\mathrm{H})=118.4, \mathrm{CHN}] ; 7.68[\mathrm{~m}, 1 \mathrm{H}, \mathrm{H} 4] ; 7.46[\mathrm{t}, 1 \mathrm{H}, 3 \mathrm{~J}(\mathrm{H}-\mathrm{H})=8.0, \mathrm{H} 5] ;\{5.00[\mathrm{~m}, 1 \mathrm{H}] ; 4.21[\mathrm{~m}$, $1 \mathrm{H}], \mathrm{CH} 2 \mathrm{~N}\} ; 3.20[\mathrm{~m}, 1 \mathrm{H}, \mathrm{CH} 2 \mathrm{NMe} 2] ;\{2.99[\mathrm{~s}, 3 \mathrm{H}] ; 2.86[\mathrm{~s}, 3 \mathrm{H}], \mathrm{NMe} 2\} ;\{2.41[\mathrm{~m}, 1 \mathrm{H}] ; 1.97[\mathrm{~m}$, $1 \mathrm{H}], \mathrm{CH} 2 \mathrm{CH} 2 \mathrm{CH} 2\} .1 \mathrm{H}$ NMR (400 MHz, $\mathrm{CDCl} 3)$ : $\mathrm{E}$ isomer $\delta 9.35[\mathrm{~s}, 1 \mathrm{H}, 3 \mathrm{~J}(\mathrm{Pt}-\mathrm{H})=60.0, \mathrm{CHN}]$; $7.56[\mathrm{~m}, 1 \mathrm{H}, \mathrm{H} 4] ; 7.37[\mathrm{t}, 1 \mathrm{H}, 3 \mathrm{~J}(\mathrm{H}-\mathrm{H})=7.2, \mathrm{H} 5] ; 4.02[\mathrm{t}, 2 \mathrm{H}, 3 \mathrm{~J}(\mathrm{H}-\mathrm{H})=6.8, \mathrm{CH} 2 \mathrm{~N}] ; 3.01[\mathrm{~s}, 6 \mathrm{H}$, $\mathrm{NMe} 2] ; 2.72$ [m, 2H, CH2NMe2]; 2.21 [m, 2H, CH2CH2CH2]. 19F NMR (376.5 MHz, CDCl3): $\delta$ -110.7 [m, Z isomer]; - 115.75 [m, E isomer]. ESI (+)-MS: 492.07 [M + NH4]+ ; 439.07 [M - Cl]+; $497.03[\mathrm{M}+\mathrm{Na}]+$. Anal. Found (calcd for C12H17Cl2FN2Pt): C, 29.7 (30.39); H, 3.5 (3.62); N, 5.7 (5.92).

$[\mathrm{PtCl} 2\{\mathrm{Me} 2 \mathrm{~N}(\mathrm{CH} 2) 3 \mathrm{~N}=\mathrm{CH}(4-\mathrm{FC} 6 \mathrm{H} 4)\}](2 \mathrm{~b})$. This compound was prepared by following the same procedure from $0.302 \mathrm{~g}(0.72 \mathrm{mmol})$ of cis-[PtCl2 $(\mathrm{dmso}) 2]$ and $0.153 \mathrm{~g}(0.73 \mathrm{mmol})$ of imine $1 \mathrm{~b}$. Yield (offwhite solid; Z isomer): $0.165 \mathrm{~g}$ (49\%). 1H NMR (400 MHz, CDCl3): $\delta 9.34$ [m, 2H, H2,6]; 8.47 [s, $1 \mathrm{H}, 3 \mathrm{~J}(\mathrm{Pt}-\mathrm{H})=115.6, \mathrm{CHN}] ; 7.27[\mathrm{t}, 2 \mathrm{H}, 3 \mathrm{~J}(\mathrm{H}-\mathrm{F})=3 \mathrm{~J}(\mathrm{H}-\mathrm{F})=8.0, \mathrm{H} 3,5] ;\{4.93[\mathrm{~m}, 1 \mathrm{H}] ; 4.13[\mathrm{~m}$, $1 \mathrm{H}], \mathrm{CH} 2 \mathrm{~N}\} ;\{3.20[\mathrm{~m}, 1 \mathrm{H}] ; 2.72[\mathrm{~m}, 1 \mathrm{H}], \mathrm{CH} 2 \mathrm{NMe} 2\} ;\{2.97[\mathrm{~s}, 3 \mathrm{H}] ; 2.84[\mathrm{~s}, 3 \mathrm{H}], \mathrm{NMe} 2\} ;\{2.50[\mathrm{~m}$, $1 \mathrm{H}] ; 1.97[\mathrm{~m}, 1 \mathrm{H}], \mathrm{CH} 2 \mathrm{CH} 2 \mathrm{CH} 2\} .19 \mathrm{~F}$ NMR $(376.5 \mathrm{MHz}, \mathrm{CDCl} 3): \delta-101.64$ [m]. ESI (+)-MS: $492.08[\mathrm{M}+\mathrm{NH} 4]+; 971.01[2 \mathrm{M}+\mathrm{Na}]+$. Anal. Found (calcd for C12H17Cl2FN2Pt): C, 31.1 (30.39); H, $3.6(3.62)$; N, 5.5 (5.92).

[PtCl2 $\{\mathrm{Me} 2 \mathrm{~N}(\mathrm{CH} 2) 2 \mathrm{~N}=\mathrm{CH}(2-\mathrm{FC} 6 \mathrm{H} 4)\}]$ (2c). This compound was prepared by following the same procedure from $0.301 \mathrm{~g}(0.71 \mathrm{mmol})$ of cis-[PtCl2 $(\mathrm{dmso}) 2]$ and $0.160 \mathrm{~g}(0.82 \mathrm{mmol})$ of imine $1 \mathrm{c}$. Yield (yellow solid; E isomer): $0.149 \mathrm{~g}(45 \%) .1 \mathrm{H} \mathrm{NMR} \mathrm{(400} \mathrm{MHz,} \mathrm{CDCl3):} \delta 9.60[\mathrm{~s}, 1 \mathrm{H}, 3 \mathrm{~J}(\mathrm{Pt}-\mathrm{H})=57.6$, $\mathrm{CHN}] ; 7.60[\mathrm{~m}, 1 \mathrm{H}, \mathrm{H} 4] ; 7.44[\mathrm{~d}, 1 \mathrm{H}, 3 \mathrm{~J}(\mathrm{H}-\mathrm{H})=7.6, \mathrm{H6}] ; 7.30[\mathrm{td}, 1 \mathrm{H}, 4 \mathrm{~J}(\mathrm{H}-\mathrm{H})=1.2,3 \mathrm{~J}(\mathrm{H}-\mathrm{H})=7.6$, $\mathrm{H} 5] ; 7.19[\mathrm{t}, 1 \mathrm{H}, 3 \mathrm{~J}(\mathrm{~F}-\mathrm{H})=9.2, \mathrm{H} 3] ; 3.82[\mathrm{t}, 2 \mathrm{H}, 3 \mathrm{~J}(\mathrm{H}-\mathrm{H})=6.0, \mathrm{CH} 2 \mathrm{~N}] ; 3.12[\mathrm{~s}, 6 \mathrm{H}, 3 \mathrm{~J}(\mathrm{Pt}-\mathrm{H})=33.2$, $\mathrm{NMe} 2$; $2.67[\mathrm{t}, 2 \mathrm{H}, 3 \mathrm{~J}(\mathrm{H}-\mathrm{H})=6.0, \mathrm{CH} 2 \mathrm{NMe} 2] .19 \mathrm{~F} \mathrm{NMR}(376.5 \mathrm{MHz}, \mathrm{CDCl} 3): \delta-108.32$ [m]. ESI 
(+)-MS: $478.06[\mathrm{M}+\mathrm{NH} 4]+$; $483.01[\mathrm{M}+\mathrm{Na}]+$. Anal. Found (calcd) for C11H15Cl2FN2Pt): C 28.4 (28.71); H 2.9 (3.29); N 6.3 (6.10).

391

[PtCl2 $\{\mathrm{Me} 2 \mathrm{~N}(\mathrm{CH} 2) 2 \mathrm{~N}=\mathrm{CH}(4-\mathrm{FC} 6 \mathrm{H} 4)\}]$ (2d). This compound was prepared by following the same procedure from $0.302 \mathrm{~g}(0.71 \mathrm{mmol})$ of cis-[PtCl2 $(\mathrm{dmso}) 2]$ and $0.150 \mathrm{~g}(0.82 \mathrm{mmol})$ of imine 1d. Yield (yellow solid; E isomer): $0.131 \mathrm{~g}(43 \%)$. $1 \mathrm{H}$ NMR (400 MHz, CDCl3): $\delta 9.47[\mathrm{~s}, 1 \mathrm{H}, 3 \mathrm{~J}(\mathrm{Pt}-\mathrm{H})=54.4$, $\mathrm{CHN}] ; 7.58[\mathrm{dd}, 2 \mathrm{H}, 4 \mathrm{~J}(\mathrm{~F}-\mathrm{H})=5.6,3 \mathrm{~J}(\mathrm{H}-\mathrm{H})=8.0, \mathrm{H} 2,6] ; 7.19[\mathrm{t}, 2 \mathrm{H}, 3 \mathrm{~J}(\mathrm{H}-\mathrm{F})=3 \mathrm{~J}(\mathrm{H}-\mathrm{H})=8.4$, $\mathrm{H} 3,5] ; 4.04[\mathrm{t}, 2 \mathrm{H}, 3 \mathrm{~J}(\mathrm{H}-\mathrm{H})=6.0, \mathrm{CH} 2 \mathrm{~N}] ; 3.13[\mathrm{~s}, 6 \mathrm{H}, \mathrm{NMe} 2] ; 2.69[\mathrm{t}, 2 \mathrm{H}, 3 \mathrm{~J}(\mathrm{H}-\mathrm{H})=6.0, \mathrm{H} 7] .19 \mathrm{~F}-$ NMR (376,5 MHz, CDCl3): $\delta-104.40[\mathrm{~m}]$. ESI (+)-MS: $478.06[\mathrm{M}+\mathrm{NH} 4]+; 483.02[\mathrm{M}+\mathrm{Na}]+$. Anal. Found18 (calcd for C11H15Cl2FN2Pt): C, 28.5 (28.71); H, 3.1 (3.29); N, 6.1 (6.10).

$[\mathrm{PtCl} 2\{\mathrm{Me} 2 \mathrm{~N}(\mathrm{CH} 2) 3 \mathrm{~N}=\mathrm{CH}(2,3,4-\mathrm{F} 3 \mathrm{C} 6 \mathrm{H})\}](2 \mathrm{~g})$. This compound was prepared by following the same procedure from $0.319 \mathrm{~g}(0.71 \mathrm{mmol})$ of cis-[PtCl2 $(\mathrm{dmso}) 2]$ and $0.173 \mathrm{~g}(0.71 \mathrm{mmol})$ of imine $1 \mathrm{~g}$. Yield (offwhite solid; mixture of $\mathrm{E}$ and $\mathrm{Z}$ isomers): $0.265 \mathrm{~g}(73 \%)$. $1 \mathrm{H} \mathrm{NMR} \mathrm{(400} \mathrm{MHz,} \mathrm{CDCl} 3$ ): $\mathrm{Z}$ isomer $\delta$ $10.75[\mathrm{~m}, 1 \mathrm{H}] ; 9.04[\mathrm{~s}, 1 \mathrm{H}, 3 \mathrm{~J}(\mathrm{Pt}-\mathrm{H})=120.0, \mathrm{CHN}] ; 7.29[\mathrm{~m}, 1 \mathrm{H}] ;\{5.00[\mathrm{~m}, 1 \mathrm{H}] ; 4.26[\mathrm{ddd}, 1 \mathrm{H}$, $\mathrm{J}(\mathrm{H}-\mathrm{H})=11.2,6.8,2.0], \mathrm{CH} 2 \mathrm{~N}\} ;\{2.97[\mathrm{~s}, 3 \mathrm{H}] ; 2.86[\mathrm{~s}, 3 \mathrm{H}], \mathrm{NMe} 2\} ; 2.73[\mathrm{~m}, 2 \mathrm{H}, \mathrm{CH} 2 \mathrm{NMe} 2] ;\{2.48$ $[\mathrm{m}, 1 \mathrm{H}] ; 2.01[\mathrm{~m}, 1 \mathrm{H}], \mathrm{CH} 2 \mathrm{CH} 2 \mathrm{CH} 2\} .1 \mathrm{H} \mathrm{NMR}(400 \mathrm{MHz}, \mathrm{CDCl} 3)$ : E isomer $\delta 9.33[\mathrm{~s}, 1 \mathrm{H}, 3 \mathrm{~J}(\mathrm{Pt}-\mathrm{H})$ $=56.0, \mathrm{CHN}] ; 7.18-7.14[\mathrm{~m}, 2 \mathrm{H}] ; 4.03[\mathrm{t}, 2 \mathrm{H}, 3 \mathrm{~J}(\mathrm{H}-\mathrm{H})=6.8, \mathrm{CH} 2 \mathrm{~N}] ; 3.00[\mathrm{~s}, 6 \mathrm{H}, \mathrm{NMe} 2] ; 2.73[\mathrm{~m}$, 2H, CH2NMe2]; 2.24 [m, 2H, CH2CH2CH2]. 19F NMR (376,5 MHz, CDCl3): Z isomer $\delta-122.53$ [m, $1 \mathrm{~F}, \mathrm{~F} 2$ ]; $-135.92[\mathrm{dddd}, 1 \mathrm{~F}, 3 \mathrm{~J}(\mathrm{~F}-\mathrm{F})=22.6,4 \mathrm{~J}(\mathrm{~F}-\mathrm{F})=15.2,3 \mathrm{~J}(\mathrm{~F}-\mathrm{H})=7.6,3 \mathrm{~J}(\mathrm{~F}-\mathrm{H})=3.8, \mathrm{~F} 4]$; $158.97[\mathrm{tdd}, 1 \mathrm{~F}, 3 \mathrm{~J}(\mathrm{~F}-\mathrm{F})=22.5,4 \mathrm{~J}(\mathrm{~F}-\mathrm{H})=7.6,5 \mathrm{~J}(\mathrm{~F}-\mathrm{H})=3.8, \mathrm{~F} 3] .19 \mathrm{~F}$ NMR $(376,5 \mathrm{MHz}, \mathrm{CDCl} 3)$ : $\mathrm{E}$ isomer: $\delta-125.98[\mathrm{~m}, 1 \mathrm{~F}] ;-130.76[\mathrm{~m}, 1 \mathrm{~F}] ;-157.03[\mathrm{tdd}, 1 \mathrm{~F}, 3 \mathrm{~J}(\mathrm{~F}-\mathrm{F})=18.8,4 \mathrm{~J}(\mathrm{~F}-\mathrm{H})=7.6$, $5 \mathrm{~J}(\mathrm{~F}-\mathrm{H})=3.8$, F3]. ESI $(+)-\mathrm{MS}: 528.06[\mathrm{M}+\mathrm{NH} 4]+; 475.05[\mathrm{M}-\mathrm{Cl}]$. Anal. Found (calcd) for C12H15Cl2F3N2Pt: C, 28.0 (28.29); H, 3.0 (2.97); N, 5.7 (5.50).

$[\mathrm{PtCl} 2\{\mathrm{Me} 2 \mathrm{~N}(\mathrm{CH} 2) 2 \mathrm{~N}=\mathrm{CH}(2,3,4-\mathrm{F} 3 \mathrm{C} 6 \mathrm{H})\}](2 \mathrm{~h})$. This compound was prepared by following the same procedure from $0.300 \mathrm{~g}(0.71 \mathrm{mmol})$ of cis-[PtCl2 $(\mathrm{dmso}) 2]$ and $0.163 \mathrm{~g}(0.71 \mathrm{mmol})$ of imine $1 \mathrm{~h}$. Yield (yellow solid; E isomer): $0.250 \mathrm{~g}(71 \%) .1 \mathrm{H} \mathrm{NMR} \mathrm{(400} \mathrm{MHz,} \mathrm{CDCl3):} \delta 9.59[\mathrm{~s}, 1 \mathrm{H}, 3 \mathrm{~J}(\mathrm{Pt}-\mathrm{H})=48.0$, $\mathrm{CHN}] ; 7.34[\mathrm{~m}, 1 \mathrm{H}] ; 7.16[\mathrm{~m}, 1 \mathrm{H}] ; 3.87[\mathrm{t}, 2 \mathrm{H}, 3 \mathrm{~J}(\mathrm{H}-\mathrm{H})=6.0, \mathrm{CH} 2 \mathrm{~N}] ; 3.13[\mathrm{~s}, 6 \mathrm{H}, \mathrm{NMe} 2] ; 2.71[\mathrm{t}, 2 \mathrm{H}$, $3 \mathrm{~J}(\mathrm{H}-\mathrm{H})=6.0, \mathrm{H} 7$ ]. 19F NMR $(376,5 \mathrm{MHz}, \mathrm{CDCl} 3): \delta-125.34$ [dddd, $1 \mathrm{~F}, 3 \mathrm{~J}(\mathrm{~F}-\mathrm{F})=18.8,4 \mathrm{~J}(\mathrm{~F}-\mathrm{F})=$ $15.0,3 \mathrm{~J}(\mathrm{~F}-\mathrm{H})=7.5,4 \mathrm{~J}(\mathrm{~F}-\mathrm{H})=3.8, \mathrm{~F} 4] ;-128.91[\mathrm{~m}, 1 \mathrm{~F}, \mathrm{~F} 2] ;-156.80[\mathrm{tdd}, 1 \mathrm{~F}, 3 \mathrm{~J}(\mathrm{~F}-\mathrm{F})=18.8$, $4 \mathrm{~J}(\mathrm{~F}-\mathrm{H})=7.5,5 \mathrm{~J}(\mathrm{~F}-\mathrm{H})=3.8, \mathrm{~F} 3]$. ESI $(+)-\mathrm{MS}: 514.04[\mathrm{M}+\mathrm{NH} 4]+$. Anal. Found (calcd for C11H13Cl2F3N2Pt): C, 26.0 (26.66); H, 3.2 (2.65); N, 5.3 (5.66).

$[\mathrm{PtCl}\{\mathrm{Me} 2 \mathrm{~N}(\mathrm{CH} 2) 3 \mathrm{~N}=\mathrm{CH}(2-\mathrm{FC} 6 \mathrm{H} 3)\}]$ (3a). This compound was obtained using method 1: a mixture of $0.250 \mathrm{~g}(0.59 \mathrm{mmol})$ of cis-[PtCl2 $(\mathrm{dmso}) 2], 0.128 \mathrm{~g}(0.61 \mathrm{mmol})$ of imine $1 \mathrm{a}$, and $0.050 \mathrm{~g}(0.61$ $\mathrm{mmol}$ ) of sodium acetate in $20 \mathrm{~mL}$ of dry methanol was refluxed for $48 \mathrm{~h}$. Upon evaporation of the solvent to $10 \mathrm{~mL}$, small amounts of compound $2 \mathrm{a}$ and metallic platinum were filtered off, and the solution was kept at $5{ }^{\circ} \mathrm{C}$ until crystallization was completed. The solid was recrystallized in $\mathrm{CH} 2 \mathrm{Cl} 2 /$ $\mathrm{MeOH}$ to produce orange crystals. Yield: $22 \mathrm{mg}(9 \%)$. Alternatively, compound 3a was prepared using method 2: a mixture of $0.150 \mathrm{~g}(0.316 \mathrm{mmol})$ of compound $2 \mathrm{a}$ and $0.026 \mathrm{~g}(0.316 \mathrm{mmol})$ of sodium acetate in $20 \mathrm{~mL}$ of dry methanol was heated under reflux for $48 \mathrm{~h}$, and the solvent was evaporated to produce an oily residue that was extracted with $5 \mathrm{~mL}$ of $\mathrm{CH} 2 \mathrm{Cl} 2$. Methanol was added, and the solution was kept at $5{ }^{\circ} \mathrm{C}$ until crystallization was completed. Yield (orange solid): $60 \mathrm{mg}$ (43.3\%). 1H NMR $(400 \mathrm{MHz}, \mathrm{CDCl} 3): \delta 8.67[\mathrm{t}, 1 \mathrm{H}, 4 \mathrm{~J}(\mathrm{H}-\mathrm{H})=1.6,3 \mathrm{~J}(\mathrm{Pt}-\mathrm{H})=142.4, \mathrm{CHN}] ; 7.80[\mathrm{~d}, 1 \mathrm{H}, 3 \mathrm{~J}(\mathrm{H}-\mathrm{H})=8.0$, $3 \mathrm{~J}(\mathrm{H}-\mathrm{Pt})=40.0, \mathrm{H} 5] ; 7.20[\mathrm{~m}, 1 \mathrm{H}, \mathrm{H} 4] ; 6.64[\mathrm{ddd}, 1 \mathrm{H}, 4 \mathrm{~J}(\mathrm{H}-\mathrm{H})=0.8,3 \mathrm{~J}(\mathrm{H}-\mathrm{H})=8.0,3 \mathrm{~J}(\mathrm{~F}-\mathrm{H})=10.0$, $\mathrm{H} 3] ; 3.92[\mathrm{~m}, 2 \mathrm{H}, \mathrm{NCH} 2] ; 2.86[\mathrm{~m}, 2 \mathrm{H}, \mathrm{CH} 2 \mathrm{NMe} 2] ; 2.85$ [s, 6H, NMe2]; 2.04 [qi, 2H, 3J(H-H) = 5.2, $\mathrm{CH} 2 \mathrm{CH} 2 \mathrm{CH} 2] .19 \mathrm{~F}$ NMR $(376.5 \mathrm{MHz}, \mathrm{CDCl} 3): \delta-115.00[\mathrm{dd}, 3 \mathrm{~J}(\mathrm{~F}-\mathrm{H})=9.8,4 \mathrm{~J}(\mathrm{~F}-\mathrm{H})=6.0$, $4 \mathrm{~J}(\mathrm{Pt}-\mathrm{F})=56.5]$. ESI $(+)-\mathrm{MS}: 438.08[\mathrm{M}+\mathrm{H}]+; 461.06[\mathrm{M}+\mathrm{Na}]+$. Anal. Found18 (calcd for C12H16ClFN2Pt): C, 33.1 (32.92); H, 3.7 (3.68); N, 6.1 (6.40). 
$[\mathrm{PtCl}\{\mathrm{Me} 2 \mathrm{~N}(\mathrm{CH} 2) 3 \mathrm{~N}=\mathrm{CH}(4-\mathrm{FC} 6 \mathrm{H} 3)\}]$ (3b). This compound was prepared by following method 2 from $0.150 \mathrm{~g}$ of $2 \mathrm{~b}$ and an equimolar amount of sodium acetate. Yield (orange solid): $50 \mathrm{mg}(36.0 \%) .1 \mathrm{H}$ $\operatorname{NMR}(400 \mathrm{MHz}, \mathrm{CDCl} 3): \delta 8.32[\mathrm{t}, 1 \mathrm{H}, 4 \mathrm{~J}(\mathrm{H}-\mathrm{H})=1.6,3 \mathrm{~J}(\mathrm{Pt}-\mathrm{H})=141.6, \mathrm{CHN}] ; 7.72[\mathrm{dd}, 1 \mathrm{H}$, $3 \mathrm{~J}(\mathrm{H}-\mathrm{Pt})=40.0,3 \mathrm{~J}(\mathrm{~F}-\mathrm{H})=10.0,4 \mathrm{~J}(\mathrm{H}-\mathrm{H})=2.4, \mathrm{H} 5] ; 7.24[\mathrm{dd}, 1 \mathrm{H}, 3 \mathrm{~J}(\mathrm{H}-\mathrm{H})=8.0,4 \mathrm{~J}(\mathrm{H}-\mathrm{F})=4.0$, $\mathrm{H} 2] ; 6.70[\mathrm{td}, 1 \mathrm{H}, 3 \mathrm{~J}(\mathrm{~F}-\mathrm{H})=3 \mathrm{~J}(\mathrm{H}-\mathrm{H})=8.5,4 \mathrm{~J}(\mathrm{H}-\mathrm{H})=2.4, \mathrm{H} 3] ; 3.86[\mathrm{~m}, 3 \mathrm{~J}(\mathrm{H}-\mathrm{Pt})=36.0,2 \mathrm{H}$, $\mathrm{NCH} 2] ; 2.85[\mathrm{~m}, 8 \mathrm{H}, \mathrm{NMe} 2+\mathrm{CH} 2 \mathrm{NMe} 2] ; 2.02[\mathrm{qi}, 2 \mathrm{H}, 3 \mathrm{~J}(\mathrm{H}-\mathrm{H})=5.3, \mathrm{CH} 2 \mathrm{CH} 2 \mathrm{CH} 2] .19 \mathrm{~F}$ NMR (376.5 MHz, CDCl3): $\delta-104.07$ [m, 1F]. 13C NMR (100.6 MHz, CDCl3): $\delta 27.23[3 \mathrm{~J}(\mathrm{C}-\mathrm{Pt})=31.0$, $\mathrm{CH} 2 \mathrm{CH} 2 \mathrm{CH} 2] ; 50.19$ [NMe2]; 57.50 [2J(C-Pt) = 38.0, NCH2]; 64.12 [CH2NMe2]; 110.37 [d, 2J(C-F) $=24.1, \mathrm{C} 3] ; 121.17[\mathrm{~d}, 2 \mathrm{~J}(\mathrm{C}-\mathrm{F})=20.1, \mathrm{C} 5] ; 129.01[\mathrm{~d}, 3 \mathrm{~J}(\mathrm{C}-\mathrm{F})=10.1, \mathrm{C} 2] ; 141.00[\mathrm{~d}, 4 \mathrm{~J}(\mathrm{C}-\mathrm{F})=2.0$, $\mathrm{C} 1] ; 146.00[\mathrm{~d}, 3 \mathrm{~J}(\mathrm{C}-\mathrm{F})=7.0, \mathrm{C} 6] ; 163.54[\mathrm{~d}, 1 \mathrm{~J}(\mathrm{C}-\mathrm{F})=257.5, \mathrm{C} 4] ; 175.13[2 \mathrm{~J}(\mathrm{C}-\mathrm{Pt})=96.6, \mathrm{CHN}]$. ESI (+)-MS: $439.07[\mathrm{M}+\mathrm{H}]+; 456.10[\mathrm{M}+\mathrm{NH} 4]+$. Anal. Found18 (calcd for C12H16ClFN2Pt): C, 32.0 (32.92); H, 3.7 (3.68); N, 6.3 (6.40).

$[\mathrm{PtCl}\{\mathrm{Me} 2 \mathrm{~N}(\mathrm{CH} 2) 2 \mathrm{~N}=\mathrm{CH}(2-\mathrm{FC} 6 \mathrm{H} 3)\}]$ (3c). This compound was prepared by following method 2 from $0.150 \mathrm{~g}$ of $2 \mathrm{c}$ and an equimolar amount of sodium acetate and increasing the reaction time to $72 \mathrm{~h}$. Yield (orange solid): $44 \mathrm{mg}(32 \%)$. $1 \mathrm{H} \mathrm{NMR}(400 \mathrm{MHz}, \mathrm{CDCl} 3): \delta 8.62[\mathrm{t}, 1 \mathrm{H}, 4 \mathrm{~J}(\mathrm{H}-\mathrm{H})=1.2,3 \mathrm{~J}(\mathrm{Pt}-\mathrm{H})=$ 144.4, CHN]; $7.29[\mathrm{~m}, 1 \mathrm{H}, \mathrm{H} 3] ; 7.23[\mathrm{t}, 3 \mathrm{~J}(\mathrm{H}-\mathrm{H})=7.8,1 \mathrm{H}, \mathrm{H} 4] ; 6.47[\mathrm{~d}, 1 \mathrm{H}, 3 \mathrm{~J}(\mathrm{H}-\mathrm{H})=8.1, \mathrm{H} 5] ; 4.03$ $[\mathrm{td}, 2 \mathrm{H}, 3 \mathrm{~J}(\mathrm{H}-\mathrm{H})=6.0,4 \mathrm{~J}(\mathrm{H}-\mathrm{H})=1.2,3 \mathrm{~J}(\mathrm{H}-\mathrm{Pt})=34.4, \mathrm{NCH} 2] ; 3.10[\mathrm{t}, 2 \mathrm{H}, 3 \mathrm{~J}(\mathrm{H}-\mathrm{H})=6.0$, $\mathrm{CH} 2 \mathrm{NMe} 2] ; 2.89$ [s, 3J(H-Pt) $=14.8,6 \mathrm{H}, \mathrm{NMe} 2]$. 19F NMR (376.5 MHz, CDCl3): $\delta-108.14$ [m, 1F]. ESI (+)-MS: $423.06[\mathrm{M}+\mathrm{H}]+$. Anal. Found18 (calcd for C11H14CIFN2Pt): C, 31.9 (31.20); H, 4.0 (3.33); N, 6.1 (6.62).

$[\mathrm{PtCl}\{\mathrm{Me} 2 \mathrm{~N}(\mathrm{CH} 2) 2 \mathrm{~N}=\mathrm{CH}(4-\mathrm{FC} 6 \mathrm{H} 3)\}]$ (3d). This compound was prepared by following method 2 from $0.150 \mathrm{~g}$ of $2 \mathrm{~d}$ and the equimolar amount of sodium acetate and increasing the reaction time to $72 \mathrm{~h}$. Yield (orange solid): $40 \mathrm{mg}(29 \%) .1 \mathrm{H} \mathrm{NMR}(400 \mathrm{MHz}, \mathrm{CDCl} 3): \delta 8.26[\mathrm{~s}, 1 \mathrm{H}, 3 \mathrm{~J}(\mathrm{Pt}-\mathrm{H})=141.2$, $\mathrm{CHN}] ; 7.41[\mathrm{dd}, 1 \mathrm{H}, 3 \mathrm{~J}(\mathrm{~F}-\mathrm{H})=9.5,4 \mathrm{~J}(\mathrm{H}-\mathrm{H})=2.8,3 \mathrm{~J}(\mathrm{H}-\mathrm{Pt})=50.8, \mathrm{H} 5] ; 7.24[\mathrm{dd}, 1 \mathrm{H}, 3 \mathrm{~J}(\mathrm{H}-\mathrm{H})=8.0$, $4 \mathrm{~J}(\mathrm{H}-\mathrm{F})=5.6, \mathrm{H} 2] ; 6.69[\mathrm{td}, 1 \mathrm{H}, 3 \mathrm{~J}(\mathrm{~F}-\mathrm{H})=3 \mathrm{~J}(\mathrm{H}-\mathrm{H})=8.8,4 \mathrm{~J}(\mathrm{H}-\mathrm{H})=2.8, \mathrm{H} 3] ; 4.06[\mathrm{t}, 2 \mathrm{H}, 3 \mathrm{~J}(\mathrm{H}-\mathrm{H})$ $=6.0, \mathrm{NCH} 2] ; 3.11[\mathrm{t}, 2 \mathrm{H}, 3 \mathrm{~J}(\mathrm{H}-\mathrm{H})=6.0, \mathrm{CH} 2 \mathrm{NMe} 2] ; 2.90$ [s, 6H, NMe2]. 19F NMR (376.5 MHz, $\mathrm{CDCl} 3): \delta-102.92[\mathrm{~m}, 1 \mathrm{~F}]$. ESI (+)-MS: $442.08[\mathrm{M}+\mathrm{NH} 4]+$. Anal. Found (calcd for C11H14ClFN2Pt): C, 30.7 (31.20); H, 3.4 (3.33); N, 6.7 (6.62).

$[\mathrm{PtCl}\{\mathrm{Me} 2 \mathrm{~N}(\mathrm{CH} 2) 3 \mathrm{~N}=\mathrm{CH}(2-\mathrm{OMe}, 3,4-\mathrm{F} 2 \mathrm{C} 6 \mathrm{H})\}](3 \mathrm{~g})$. This compound was prepared following method 2 from $0.150 \mathrm{~g}$ of $2 \mathrm{~g}$ and an equimolar amount of sodium acetate and increasing the reaction time to 72 h. Yield (orange solid): $40 \mathrm{mg}(28 \%)$. $1 \mathrm{H}$ NMR $(400 \mathrm{MHz}, \mathrm{CDCl} 3): \delta 8.59[\mathrm{~s}, 1 \mathrm{H}, 3 \mathrm{~J}(\mathrm{Pt}-\mathrm{H})=144.0$, $\mathrm{CHN}] ; 7.48[\mathrm{dd}, 1 \mathrm{H}, 3 \mathrm{~J}(\mathrm{~F}-\mathrm{H})=11.5,4 \mathrm{~J}(\mathrm{H}-\mathrm{F})=7.5, \mathrm{H} 5]$; $4.01[\mathrm{~d}, 3 \mathrm{H}, 5 \mathrm{~J}(\mathrm{H}-\mathrm{F})=4.0, \mathrm{OMe}] ; 3.86[\mathrm{t}$, $2 \mathrm{H}, 3 \mathrm{~J}(\mathrm{H}-\mathrm{H})=4.0, \mathrm{NCH} 2] ; 2.83[\mathrm{~m}, 8 \mathrm{H}, \mathrm{NMe} 2+\mathrm{CH} 2 \mathrm{NMe} 2] ; 2.01[\mathrm{~m}, 2 \mathrm{H}, \mathrm{CH} 2 \mathrm{CH} 2 \mathrm{CH} 2]$. 19F NMR $(376.5 \mathrm{MHz}, \mathrm{CDCl} 3): \delta-127.20[\mathrm{dd}, 1 \mathrm{~F}, 3 \mathrm{~J}(\mathrm{~F}-\mathrm{F})=18.8,3 \mathrm{~J}(\mathrm{H}-\mathrm{F})=11.3,4 \mathrm{~J}(\mathrm{H}-\mathrm{Pt})=45.2, \mathrm{~F} 4]$; $163.15[\mathrm{ddq}, 1 \mathrm{~F}, 3 \mathrm{~J}(\mathrm{~F}-\mathrm{F})=18.8,4 \mathrm{~J}(\mathrm{H}-\mathrm{F})=7.5,5 \mathrm{~J}(\mathrm{H}-\mathrm{F})=3.8$, F3]. HRESI $(+)-\mathrm{MS}: \mathrm{m} / \mathrm{z}$ 486.0705, calcd for C13H18F2ClN2OPt [M + H]+ 486.0718; 450.0937, calcd for C13H17F2N2OPt [M - Cl]+ 450.0951. Anal. Found (calcd for C13H17F2ClN2OPt): C, 31.7 (32.16); H, 3.5 (3.53); N, 5.6 (5.77).

$[\mathrm{PtCl}\{\mathrm{Me} 2 \mathrm{~N}(\mathrm{CH} 2) 2 \mathrm{~N}=\mathrm{CH}(2-\mathrm{OMe}, 3,4-\mathrm{F} 2 \mathrm{C} 6 \mathrm{H})\}]$ (3h). This compound was prepared by following method 2 from $0.150 \mathrm{~g}$ of $2 \mathrm{~h}$ and an equimolar amount of sodium acetate and increasing the reaction time to $72 \mathrm{~h}$. Yield (orange solid): $42 \mathrm{mg}(29 \%)$. $1 \mathrm{H} \mathrm{NMR} \mathrm{(400} \mathrm{MHz,} \mathrm{CDCl3):} \delta 8.56[\mathrm{~s}, 1 \mathrm{H}, 3 \mathrm{~J}(\mathrm{Pt}-\mathrm{H})$ $=140.0, \mathrm{CHN}] ; 7.17[\mathrm{dd}, 1 \mathrm{H}, 3 \mathrm{~J}(\mathrm{~F}-\mathrm{H})=11.5,4 \mathrm{~J}(\mathrm{H}-\mathrm{F})=7.5, \mathrm{H} 5] ; 4.06[\mathrm{t}, 2 \mathrm{H}, 3 \mathrm{~J}(\mathrm{H}-\mathrm{H})=6.0, \mathrm{NCH} 2]$; $4.02[\mathrm{~d}, 3 \mathrm{H}, 5 \mathrm{~J}(\mathrm{H}-\mathrm{F})=3.2, \mathrm{OMe}] ; 3.01[\mathrm{t}, 2 \mathrm{H}, 3 \mathrm{~J}(\mathrm{H}-\mathrm{H})=6.0, \mathrm{CH} 2 \mathrm{NMe} 2] ; 2.89[\mathrm{~s}, 6 \mathrm{H}, 3 \mathrm{~J}(\mathrm{Pt}-\mathrm{H})=$ 15.2, NMe2]. 19F NMR (376.5 MHz, CDCl3): $\delta-126.14[\mathrm{dd}, 1 \mathrm{~F}, 3 \mathrm{~J}(\mathrm{~F}-\mathrm{F})=18.8,3 \mathrm{~J}(\mathrm{H}-\mathrm{F})=12.0, \mathrm{~F} 4]$; $-163.00[\mathrm{ddq}, 1 \mathrm{~F}, 3 \mathrm{~J}(\mathrm{~F}-\mathrm{F})=18.8,4 \mathrm{~J}(\mathrm{H}-\mathrm{F})=7.5,5 \mathrm{~J}(\mathrm{H}-\mathrm{F})=3.8$, F3]. ESI $(+)-\mathrm{MS}: 472.05[\mathrm{M}+\mathrm{H}]+$. Anal. Found (calcd for C12H15F2ClN2OPt): C, 30.4 (30.57); H, 3.4 (3.21); N, 5.8 (5.94).

[PtMe $\{\mathrm{Me} 2 \mathrm{~N}(\mathrm{CH} 2) 3 \mathrm{~N}=\mathrm{CH}(2-\mathrm{FC} 6 \mathrm{H} 3)\}]$ (4a). This compound was obtained using the following procedure: $0.100 \mathrm{~g}(0.17 \mathrm{mmol})$ of [Pt2Me4( $\mu$-SMe2)2] and $0.072 \mathrm{~g}(0.34 \mathrm{mmol})$ of imine 1a were dissolved in $20 \mathrm{~mL}$ of toluene, and the obtained solution was refluxed for $1 \mathrm{~h}$. The solvent was removed, 
and the residue was treated with diethyl ether to give a red solid. Yield: $115 \mathrm{mg}(79 \%)$. 1H NMR (400 $\mathrm{MHz}, \mathrm{CDCl} 3): \delta 8.91[\mathrm{~s}, 1 \mathrm{H}, 3 \mathrm{~J}(\mathrm{Pt}-\mathrm{H})=60.4, \mathrm{CHN}] ; 7.44[\mathrm{~d}, 1 \mathrm{H}, 3 \mathrm{~J}(\mathrm{Pt}-\mathrm{H})=64.0,3 \mathrm{~J}(\mathrm{H}-\mathrm{H})=8.0$, $\mathrm{H} 5] ; 7.17[\mathrm{td}, 1 \mathrm{H}, 3 \mathrm{~J}(\mathrm{H}-\mathrm{H})=8.0,4 \mathrm{~J}(\mathrm{H}-\mathrm{F})=6.4, \mathrm{H} 4] ; 6.61[\mathrm{ddd}, 1 \mathrm{H}, 3 \mathrm{~J}(\mathrm{~F}-\mathrm{H})=10.4,3 \mathrm{~J}(\mathrm{H}-\mathrm{H})=8.0$, $4 \mathrm{~J}(\mathrm{H}-\mathrm{H})=0.8, \mathrm{H} 3] ; 3.89[\mathrm{~m}, 2 \mathrm{H}, \mathrm{NCH} 2] ; 2.91[\mathrm{~m}, 2 \mathrm{H}, \mathrm{CH} 2 \mathrm{NMe} 2] ; 2.73[\mathrm{~s}, 6 \mathrm{H}, 3 \mathrm{~J}(\mathrm{Pt}-\mathrm{H})=24.0$, $\mathrm{NMe} 2$ ]; 2.03 [qi, 2H, 3J(H-H) = 5.6, CH2CH2CH2]; 1.02 [s, 3H, 2J(Pt-H) = 80.0, Me-Pt]. 19F NMR $(376.5 \mathrm{MHz}, \mathrm{CDCl} 3): \delta-117.53[\mathrm{dd}, 1 \mathrm{~F}, 3 \mathrm{~J}(\mathrm{~F}-\mathrm{H})=11.3,4 \mathrm{~J}(\mathrm{~F}-\mathrm{H})=7.5,4 \mathrm{~J}(\mathrm{Pt}-\mathrm{F})=56.5]$. ESI (+)-MS: $443.12[\mathrm{M}-\mathrm{H}+\mathrm{CH} 3 \mathrm{CN}]+$. Anal. Found (calcd for C13H19FN2Pt): C, 37.8 (37.41); H, 4.8 (4.59); N, $6.3(6.71)$.

[PtMe $\{\mathrm{Me} 2 \mathrm{~N}(\mathrm{CH} 2) 3 \mathrm{~N}=\mathrm{CH}(4-\mathrm{FC} 6 \mathrm{H} 3)\}]$ (4b). This compound was obtained by using the same procedure from $0.100 \mathrm{~g}(0.17 \mathrm{mmol})$ of [Pt2Me4( $\mu-\mathrm{SMe} 2) 2]$ and $0.078 \mathrm{~g}(0.35 \mathrm{mmol})$ of imine $1 \mathrm{~b}$. Yield (red solid): $105 \mathrm{mg}$ (72\%). 1H NMR (400 MHz, d6-acetone): $\delta 8.66[\mathrm{~s}, 1 \mathrm{H}, 3 \mathrm{~J}(\mathrm{Pt}-\mathrm{H})=62.8$, $\mathrm{CHN}] ; 7.32[\mathrm{~m}, 1 \mathrm{H}, \mathrm{H} 2] ; 7.21[\mathrm{dd}, 1 \mathrm{H}, 3 \mathrm{~J}(\mathrm{H}-\mathrm{F})=11.2,4 \mathrm{~J}(\mathrm{H}-\mathrm{H})=2.5,3 \mathrm{~J}(\mathrm{Pt}-\mathrm{H})=35.6, \mathrm{H} 5] ; 6.60$ $[\mathrm{ddd}, 1 \mathrm{H}, 3 \mathrm{~J}(\mathrm{~F}-\mathrm{H})=9.1,3 \mathrm{~J}(\mathrm{H}-\mathrm{H})=8.0,4 \mathrm{~J}(\mathrm{H}-\mathrm{H})=2.0, \mathrm{H} 3] ; 3.85[\mathrm{t}, 2 \mathrm{H}, \mathrm{J}(\mathrm{H}-\mathrm{H})=5.0, \mathrm{NCH} 2] ; 2.87$ $[\mathrm{m}, 2 \mathrm{H}, \mathrm{CH} 2 \mathrm{NMe} 2] ; 2.66[\mathrm{~s}, 6 \mathrm{H}, 3 \mathrm{~J}(\mathrm{Pt}-\mathrm{H})=23.3, \mathrm{NMe} 2] ; 1.99$ [m, 2H, CH2CH2CH2]; 0.81 [s, 3H, $2 \mathrm{~J}(\mathrm{Pt}-\mathrm{H})=81.7$, Me-Pt]. 19F-NMR (376.5 MHz, CDCl3): $\delta-107.58[\mathrm{ddd}, 1 \mathrm{~F}, 3 \mathrm{~J}(\mathrm{~F}-\mathrm{H})=11.3$, $3 \mathrm{~J}(\mathrm{~F}-\mathrm{H})=7.5,4 \mathrm{~J}(\mathrm{~F}-\mathrm{H})=3.7,4 \mathrm{~J}(\mathrm{~F}-\mathrm{Pt})=71.5]$. ESI $(+)-\mathrm{MS}: 443.12[\mathrm{M}-\mathrm{H}+\mathrm{CH} 3 \mathrm{CN}]+$. Anal. Found (calcd for C13H19FN2Pt-2H2O): C, 34.5 (34.44); H, 4.8 (5.11); N, 6.0 (6.17).

[PtMe $\{\mathrm{Me} 2 \mathrm{~N}(\mathrm{CH} 2) 2 \mathrm{~N}=\mathrm{CH}(4-\mathrm{FC} 6 \mathrm{H} 3)\}]$ (4d). This compound was obtained by using the same procedure from $0.100 \mathrm{~g}(0.17 \mathrm{mmol})$ of [Pt2Me4( $\mu-\mathrm{SMe} 2) 2]$ and $0.068 \mathrm{~g}(0.35 \mathrm{mmol})$ of imine $1 \mathrm{~d}$. Yield (red solid): $109 \mathrm{mg}$ (77\%). 1H NMR (400 MHz, d6-acetone): $\delta 8.71[\mathrm{~s}, 1 \mathrm{H}, 3 \mathrm{~J}(\mathrm{Pt}-\mathrm{H})=61.0$, $\mathrm{CHN}] ; 7.30[\mathrm{dd}, 3 \mathrm{~J}(\mathrm{H}-\mathrm{H})=8.0,4 \mathrm{~J}(\mathrm{H}-\mathrm{F})=6.0,4 \mathrm{~J}(\mathrm{H}-\mathrm{Pt})=27.0,1 \mathrm{H}, \mathrm{H} 2] ; 7.10[\mathrm{dd}, 1 \mathrm{H}, 3 \mathrm{~J}(\mathrm{H}-\mathrm{F})=$ $10.4,4 \mathrm{~J}(\mathrm{H}-\mathrm{H})=2.6,3 \mathrm{~J}(\mathrm{Pt}-\mathrm{H})=85.0, \mathrm{H} 5] ; 6.57[\mathrm{ddd}, 1 \mathrm{H}, 3 \mathrm{~J}(\mathrm{~F}-\mathrm{H})=9.2,3 \mathrm{~J}(\mathrm{H}-\mathrm{H})=8.0,4 \mathrm{~J}(\mathrm{H}-\mathrm{H})=$ 2.6, H3]; $4.11[\mathrm{t}, 2 \mathrm{H}, 3 \mathrm{~J}(\mathrm{H}-\mathrm{H})=6.0, \mathrm{NCH} 2] ; 3.18[\mathrm{t}, 2 \mathrm{H}, 3 \mathrm{~J}(\mathrm{H}-\mathrm{H})=6.0, \mathrm{CH} 2 \mathrm{NMe} 2] ; 2.77[\mathrm{~s}, 6 \mathrm{H}$, $3 \mathrm{~J}(\mathrm{Pt}-\mathrm{H})=21.0, \mathrm{NMe} 2] ; 0.77$ [s, 3H, 2J(Pt-H) $=79.0, \mathrm{Me}-\mathrm{Pt}] .19 \mathrm{~F} \mathrm{NMR}(376.5 \mathrm{MHz}, \mathrm{CDCl} 3): \delta$ $-106.64[\mathrm{td}, 1 \mathrm{~F}, 3 \mathrm{~J}(\mathrm{~F}-\mathrm{H})=9.5,4 \mathrm{~J}(\mathrm{~F}-\mathrm{H})=5.9,4 \mathrm{~J}(\mathrm{~F}-\mathrm{Pt})=88.0]$. ESI $(+)-\mathrm{MS}: 429.10[\mathrm{M}-\mathrm{H}+$ $\mathrm{CH} 3 \mathrm{CN}]+; 401.09$ [M - Me + CH3CN]+. Anal. Found18 (calcd for C12H17FN2Pt): C, 34.5 (35.72); H, 4.2 (4.25); N, 6.7 (6.95).

[PtMe $\{\mathrm{Me} 2 \mathrm{~N}(\mathrm{CH} 2) 3 \mathrm{~N}=\mathrm{CHC} 6 \mathrm{H} 4\}]$ (4e). This compound was obtained by using the same procedure from $0.100 \mathrm{~g}(0.17 \mathrm{mmol})$ of [Pt2Me4( $\mu$-SMe2)2] and $0.065 \mathrm{~g}(0.35 \mathrm{mmol})$ of imine 1e. Yield (red solid): $95 \mathrm{mg}(69 \%) .1 \mathrm{H} \mathrm{NMR}$ (400 MHz, d6-acetone): $\delta 8.49$ [s, $1 \mathrm{H}, 3 \mathrm{~J}(\mathrm{Pt}-\mathrm{H})=60.0, \mathrm{CHN}$ ]; $7.61[\mathrm{~d}$, $3 \mathrm{~J}(\mathrm{H}-\mathrm{H})=7.6,3 \mathrm{~J}(\mathrm{H}-\mathrm{Pt})=64.0,1 \mathrm{H}, \mathrm{H} 5] ; 7.20[\mathrm{~m}, 1 \mathrm{H}] ; 7.07[\mathrm{t}, 1 \mathrm{H}, 3 \mathrm{~J}(\mathrm{H}-\mathrm{H})=8.2, \mathrm{H} 4] ; 6.88[\mathrm{t}, 1 \mathrm{H}$, $3 \mathrm{~J}(\mathrm{H}-\mathrm{H})=7.4, \mathrm{H} 3] ; 3.78[\mathrm{t}, 2 \mathrm{H}, 3 \mathrm{~J}(\mathrm{H}-\mathrm{H})=4.8, \mathrm{NCH} 2] ; 2.84$ [m, 2H, CH2NMe2]; $2.66[\mathrm{~s}, 6 \mathrm{H}$, $3 \mathrm{~J}(\mathrm{Pt}-\mathrm{H})=22.4, \mathrm{NMe} 2] ; 1.95[\mathrm{qi}, 2 \mathrm{H}, 3 \mathrm{~J}(\mathrm{H}-\mathrm{H})=5.5, \mathrm{CH} 2 \mathrm{CH} 2 \mathrm{CH} 2] ; 0.93[\mathrm{~s}, 3 \mathrm{H}, 2 \mathrm{~J}(\mathrm{Pt}-\mathrm{H})=81.0$, Me-Pt]. ESI (+)-MS: $425.13[\mathrm{M}-\mathrm{H}+\mathrm{CH} 3 \mathrm{CN}]+; 383.10[\mathrm{M}-\mathrm{Me}]+$. Anal. Found (calcd for C13H20N2Pt·H2O): C, 37.1 (37.41); H, $5.0(5.31) ; \mathrm{N}, 6.1$ (6.71).

[PtMe $\{\mathrm{Me} 2 \mathrm{~N}(\mathrm{CH} 2) 3 \mathrm{~N}=\mathrm{CH}(2,3,4-\mathrm{F} 3 \mathrm{C} 6 \mathrm{H})\}](4 \mathrm{~g})$. This compound was obtained by using the same procedure from $0.100 \mathrm{~g}(0.17 \mathrm{mmol})$ of [Pt2Me4( $\mu-\mathrm{SMe} 2) 2]$ and $0.085 \mathrm{~g}(0.36 \mathrm{mmol})$ of imine $1 \mathrm{~g}$. Yield (red solid): $102 \mathrm{mg}(65 \%)$. $1 \mathrm{H}$ NMR (400 MHz, d6-acetone): $\delta 8.85[\mathrm{~s}, 1 \mathrm{H}, 3 \mathrm{~J}(\mathrm{Pt}-\mathrm{H})=60.0$, $\mathrm{CHN}$ ]; $7.21[\mathrm{ddd}, 1 \mathrm{H}, 3 \mathrm{~J}(\mathrm{H}-\mathrm{F})=9.0,4 \mathrm{~J}(\mathrm{H}-\mathrm{F})=7.2,5 \mathrm{~J}(\mathrm{H}-\mathrm{F})=2.0, \mathrm{H} 5] ; 3.89[\mathrm{t}, 2 \mathrm{H}, \mathrm{J}(\mathrm{H}-\mathrm{H})=4.0$, $\mathrm{NCH} 2] ; 2.91[\mathrm{~m}, 2 \mathrm{H}, \mathrm{CH} 2 \mathrm{NMe} 2] ; 2.73$ [s, 6H, 3J(Pt-H) = 24.0, NMe2]; 2.03 [qi, 2H, 3J(H-H) = 5.5, $\mathrm{CH} 2 \mathrm{CH} 2 \mathrm{CH} 2$ ]; 0.95 [s, 3H, 2J $(\mathrm{Pt}-\mathrm{H})=80.0$, Me- Pt]. 19F NMR (376.5 MHz, CDCl3): $\delta-129.20$ [ddd, $1 \mathrm{~F}, 3 \mathrm{~J}(\mathrm{~F}-\mathrm{F})=19.4,3 \mathrm{~J}(\mathrm{~F}-\mathrm{H})=10.7,4 \mathrm{~J}(\mathrm{~F}-\mathrm{F})=7.5, \mathrm{~F} 4] ;-139.23[\mathrm{dd}, 1 \mathrm{~F}, 3 \mathrm{~J}(\mathrm{~F}-\mathrm{F})=19.4,4 \mathrm{~J}(\mathrm{~F}-\mathrm{F})=$ 7.5, F2]; $-170.41[\mathrm{td}, 1 \mathrm{~F}, 3 \mathrm{~J}(\mathrm{~F}-\mathrm{F})=19.4,4 \mathrm{~J}(\mathrm{~F}-\mathrm{H})=7.5$, F3];. ESI (+)-MS: $437.07[\mathrm{M}-\mathrm{Me}]+; 479.10$ $[\mathrm{M}-\mathrm{Me}+\mathrm{CH} 3 \mathrm{CN}]+; 891.2[2 \mathrm{M}-\mathrm{Me}]+$. Anal. Found (calcd for C13H17F3N2Pt $\mathrm{H} 2 \mathrm{O}$ ): C, 33.5 (33.11); H, 4.1 (4.06); N, 5.8 (5.94).

X-ray Diffraction. Suitable crystals were grown in dichloromethane-methanol at room temperature. Xray intensity data were measured on a D8 VENTURE system equipped with a multilayer monochromator and a Mo high brilliance microfocus source $(\lambda=0.71073 \AA)$ at $100 \mathrm{~K}$. For $3 \mathrm{~b}$, the 
532 integration of the data using a monoclinic unit cell yielded a total of 197137 reflections to a maximum $\theta$ 533 angle of $25.11^{\circ}(0.84 \AA$ resolution $), 18361$ of which were independent and 16383 were greater than $5342 \sigma(\mathrm{F} 2)$. Data were corrected for absorption effects using the multiscan method. For $3 \mathrm{~g}$, the integration of 535 the data using a monoclinic unit cell yielded a total of 14556 reflections to a maximum $\theta$ angle of $30.54^{\circ}$ 536 (0.70 A resolution), 3778 of which were independent and 3142 were greater than $2 \sigma(\mathrm{F} 2)$. The structures 537 were solved and refined using the Bruker SHELXTL software package.22 Further information is given 538 in Table S1 (Supporting Information). 


\section{AUTHOR INFORMATION}

541

542 Corresponding Author

543 *M.C.: tel, +34934039132; fax, +34934907725; e-mail, margarita.crespo@qi.ub.es . L.R.: tel,

544 +34934039130; fax, +34934907725; e-mail, laura.rodriguez@,qi.ub.es.

545

$546 \quad$ Notes

547 The authors declare no competing financial interests.

548 
549 ACKNOWLEDGMENTS

550

551 This work was supported by the Ministerio de Ciencia y Tecnologiá (project CTQ2009-11501) and by 552 the Ministerio de Economiá y Competitividad (project CTQ2012-31335).

553 


\section{REFERENCES}

(1) (a) Kalinowski, J.; Fattori, V.; Cocchi, M.; Williams, J. A. G. Coord. Chem. Rev. 2011, 255, 2401-2425. (b) Williams, J. A. G.; Develay, S.; Rochester, D. L.; Murphy, L. Coord. Chem. Rev. 2008, 252, 2596-2611. (c) Turner, E.; Bakken, N.; Li, J. Inorg. Chem. 2013, 52, 7344-7351. (d) Li, Z.; Sun, W. Dalton Trans. 2013, 42, 14021-14029.

(2) See for instance: (a) Lu, W.; Chan, M. C. W.; Cheung, K.-K.; Che, C.-M. Organometallics 2001, 20, 2477-2486. (b) Williams, J. A. G.; Beeby, A.; Davies, E. S.; Weinstein, J. A.; Wilson, C. Inorg. Chem. 2003, 42, 8609-8611. (c) Williams, J. A. G. Chem. Soc. Rev. 2009, 38, 1783-1801. (d) Wang, Z.; Turner, E.; Mahoney, V.; Madakuni, S.; Groy, T.; Li, J. Inorg. Chem. 2010, 49, 11276-11286. (e) Murphy, L.; Brulatti, P.; Fattori, V.; Cocchi, M.; Williams, J. A. G. Chem. Commun. 2012, 48, 5817-5819. (f) Kui, S. C. F.; Hung, F.-F.; Lai, S.-L.; Yuen, M.-Y.; Kwok, C.-C.; Low, K.-H.; Chui, S. S.-Y.; Che, C.-M. Chem. Eur. J. 2012, 18, 96-109. (g) Zhang, L.-K.; Xing, L.-B.; Chen, B.; Yang, Q.-Z.; Tong, Q.-X.; Wu, L.-Z.; Tung, C.-H. Dalton Trans. 2013, 42, 4244-4247. (h) Li, Z.; Badaeva, E.; Ugrinov, A.; Kilina, S.; Sun, W. Inorg. Chem. 2013, 52, 7578-7592.

(3) (a) Brooks, J.; Babayan, Y.; Lamansky, S.; Djurovich, P. I.; Tsyba, I.; Bau, R.; Thompson, M. E. Inorg. Chem. 2002, 41, 3055-3066. (b) Mróz, W.; Botta, C.; Giovanella, U.; Rossi, E.; Colombo, A.; Dragonetti, C.; Roberto, D.; Ugo, R.; Valore, A.; Williams, J. A. G. J. Mater. Chem. 2011, 21, 8653-8661.

(4) (a) Scaffidi-Domianello, Y. Y.; Nazarov, A. A.; Haukka, M.; Galanski, M.; Keppler, B. K.; Schneider, J.; Du, P.; Eisenberg, R.; Kukushin, V. Y. Inorg. Chem. 2007, 46, 4469-4482. (b) Caubet, A.; Loṕ ez, C.; Solans, X.; Font-Bardıá , M. J. Organomet. Chem. 2003, 669, 164-171. (c) Pandya, S. U.; Moss, K. C.; Bryce, M. R.; Batsanov, A. S.; Fox, M. A.; Jankus, V.; Al Attar, H. A.; Monkman, A. P. Eur. J. Inorg. Chem. 2010, 1963-1972. (d) Blackburn, O. A.; Coe, B. J.; Helliwell, M.; Raftery, J. Organometallics 2012, 31, 5307-5320. (e) Anderson, C. M.; Weinstein, M. A.; Morris, J.; Kfoury, N.; Duman, L.; Balema, T. A.; Kreider-Mueller, A.; Scheetz, P.; Ferrara, S.; Chierchia, M.; Tanski, J. M. J. Organomet. Chem. 2013, 723, 188-197. 
(5) Capape, A.; Crespo, M.; Granell, J.; Font-Bardı́ , M.; Solans, X. J. Organomet. Chem. 2005, $690,4309-4318$

(6) Crespo, M.; Font-Bardıá , M.; Granell, J.; Martı́ ez, M.; Solans, X. Dalton Trans. 2003, $3763-3769$.

(a) Ranatunge-Bandarage, P. R. R.; Robinson, B. H.; Simpson, J. Organometallics 1994, 13, 500-510. (b) Wu, Y. J.; Ding, L.; Wang, H. X.; Liu, Y. H.; Yuan, H. Z.; Mao, X. A. J. Organomet. Chem. 1997, 535, 49-58. (c) Ryabov, A. D.; Panyashkina, I. M.; Polyakov, V. A.; Fisher, A. Organometallics 2002, 21, 1633-1636. (d) Pérez, S.; López, C.; Caubet, A.; Solans, X.; Font-Bard1á , M. New J. Chem. 2003, 27, 975- 982.

(8) (a) Crespo, M.; Font-Bardı́ , M.; Solans, X. J. Organomet. Chem. 2006, 691, 1897-1906. (b) Crespo, M.; Anderson, C. M.; Tanski, J. M. Can. J. Chem. 2009, 87, 80-87. (c) Bernhardt, P. V.; Calvet, T.; Crespo, M.; Font-Bardıá , M.; Jansat, S.; Martı́ ez, M. Inorg. Chem. 2013, 52, $474-484$.

(9) Buckley, H. L.; Wang, T.; Tran, O.; Love, J. A. Organometallics 2009, 28, 2356-2359.

(10) (a) Crespo, M. Organometallics 2012, 31, 1216-1234. (b) Crespo, M.; Martı́n , R.; Calvet, T.; Font-Bardıá , M.; Solans, X. Polyhedron 2008, 27, 2603-2611.

(11) Bizier, N. P.; Wackerly, J. W.; Braunstein, E. D.; Zhang, M.; Nodder, S. T.; Carlin, S. M.; Katz, J. L. J. Org. Chem. 2013, 78, 5987-5998.

(12) Kozhevnikov, V. N.; Dahms, K.; Bryce, M. R. J. Org. Chem. 2011, 76, 5143-5148.

(13) Lutnaes, B. F.; Luthe, G.; Brinkman, U. A. Th.; Johansen, J. E.; Krane, J. Magn. Reson. Chem. $2005,43,588-594$.

(14) (a) Anderson, C. M.; Crespo, M.; Jennings, M. C.; Lough, A. J.; Ferguson, G.; Puddephatt, R. J. Organometallics 1991, 10, 2672-2679. (b) Loṕ ez, O.; Crespo, M.; Font-Bardıá , M.; Solans, X. Organometallics 1997, 16, 1233-1240. (c) Anderson, C. M.; Crespo, M.; Ferguson, G.; Lough, A. J.; Puddephatt, R. J. Organometallics 1992, 11, 1177-1181.

(15) (a) Kourkoulos, D.; Karakus, C.; Hertel, D.; Alle, R.; Schmeding, S.; Hummel, J.; Risch, N.; Holder, E.; Meerholz, K. Dalton Trans. 2013, 42, 13612-13621. (b) Kui, S. C. F.; Sham, I. H. T.; Cheung, C. C. C.; Ma, C.-W.; Yan, B.; Zhu, N.; Che, C.-M.; Fu, W.-F. Chem. Eur. J. 2007, 
(16) Komiya, N.; Kahiwabara, T.; Iwata, S.; Naota, T. J. Organomet. Chem. 2013, 738, 66-75.

(17) (a) Garner, K. L.; Parkes, L. F.; Piper, J. D.; Williams, J. A. G. Inorg. Chem. 2010, 49, 476-487.

(b) Vezzu, D. A. K.; Ravindranathan, D.; Garner, A. W.; Bartolotti, L.; Smith, M. E.; Boyle, P. D.; Huo, S. Inorg. Chem. 2011, 50, 8261-8273.

(18) The analyses of fluorinated compounds present significant difficulty; see: Fadeeva, V. P.;

(19) Van Houten, J.; Watts, R. J. J. Am. Chem. Soc. 1976, 98, 4853-4858.

622

(20) Kukushkin, V. Y.; Pombeiro, A. J. L; Ferreira, C. M. P.; Elding, L. I. Inorg. Synth. 2002, 33, 189-196.

(21) Hill, G. S.; Irwin, M. J.; Levy, C. J.; Rendina, L. M.; Puddephatt, R. J. Inorg. Synth. 1998, 32, $149-153$.

(22) Sheldrick, G. M. SHELXL program for refinement of crystal structures. Acta Crystallogr. 2008, A64, 112-122. 
Scheme 1. Synthesis of Compounds 3

633

634

Scheme 2. Synthesis of Compounds 3g,h with Fluoro for Methoxy Substitution

635

636

Figure 1. Molecular structure of compound 3b (molecule a). Selected bond lengths $(\AA)$ and angles (deg)

with estimated standard deviations: $\operatorname{Pt}(1 \mathrm{a})-\mathrm{N}(1 \mathrm{a}), 1.986(9) ; \operatorname{Pt}(1 \mathrm{a})-\mathrm{C}(1 \mathrm{a}), 1.998(10) ; \operatorname{Pt}(1 \mathrm{a})-\mathrm{N}(2 \mathrm{a})$,

2.174(8); Pt(1a)-Cl(1a), 2.297(3); N(2a)-C(10a), 1.483(15); C(10a)-C(9a), 1.53(2); C(9a)-C(8a),

1.53(2); C(8a)-N(1a), 1.467(15); N(1a)-C(7a), 1.293(15); C(7a)-C(6a), 1.430(18); C(6a)-C(1a),

$\mathrm{N}(2 \mathrm{a})-\mathrm{Pt}(1 \mathrm{a})-\mathrm{Cl}(1 \mathrm{a}), 89.5(3)$.

642

Figure 2. Molecular structure of compound 3g. Selected bond lengths $(\AA)$ and angles (deg) with estimated standard deviations: $\mathrm{Pt}(1)-\mathrm{N}(1), 1.997(4) ; \operatorname{Pt}(1)-\mathrm{C}(1), 2.000(3) ; \operatorname{Pt}(1)-\mathrm{N}(2), 2.174(3)$;

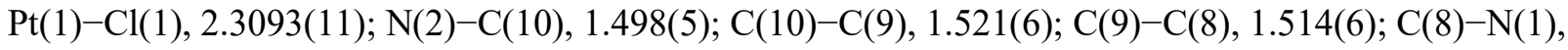

$\mathrm{N}(1)-\operatorname{Pt}(1)-\mathrm{C}(1), 80.76(15) ; \mathrm{C}(1)-\operatorname{Pt}(1)-\mathrm{Cl}(1), 92.85(13) ; \mathrm{N}(2)-\operatorname{Pt}(1)-\mathrm{Cl}(1), 89.61(10)$.

Scheme 3. Synthesis of Compounds 4

650

651

Figure 3. Absorption spectra of compounds 3 in dichloromethane solution at $298 \mathrm{~K}$ at $10-4 \mathrm{M}$ concentration.

Figure 4. Emission spectra of compounds 3 in dichloromethane solution at $298 \mathrm{~K}$ : $\lambda \operatorname{exc} 388$ (3a), 376 (3b), 400 (3c), 391 (3d), 383 (3e), 391 (3f), 383 (3g), 391 nm (3h); concentration 10-4 M; three slits. comparison purposes.

Figure 5. Absorption spectra of compounds 4 in dichloromethane solution at $298 \mathrm{~K}$ at $10-4 \mathrm{M}$ concentration.

Figure 6. Emission spectra of compounds 4 in dichloromethane solution at $77 \mathrm{~K}$ : $\lambda \operatorname{exc} 405$ (4a), 390 (4b), 415 (4c), 400 (4d), 400 (4e), 409 (4f), 402 (4g), $410 \mathrm{~nm}$ (4h); concentration 10-4 M; three slits. comparison purposes. 


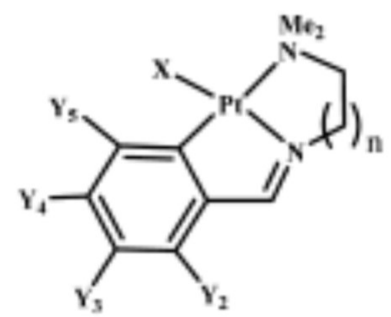

$\begin{array}{lllllll} & \mathbf{X} & \mathbf{Y}_{2} & \mathbf{Y}_{3} & \mathbf{Y}_{4} & \mathbf{Y}_{3} & \text { n } \\ \text { 3a } & \mathrm{Cl} & \mathrm{F} & \mathrm{H} & \mathrm{H} & \mathrm{H} & 2 \\ \text { 3b } & \mathrm{Cl} & \mathrm{H} & \mathrm{H} & \mathrm{F} & \mathrm{H} & 2 \\ \text { 3c } & \mathrm{Cl} & \mathrm{F} & \mathrm{H} & \mathrm{H} & \mathrm{H} & 1 \\ \text { 3d } & \mathrm{Cl} & \mathrm{H} & \mathrm{H} & \mathrm{F} & \mathrm{H} & 1 \\ \text { 3e } & \mathrm{Cl} & \mathrm{H} & \mathrm{H} & \mathrm{H} & \mathrm{H} & 2 \\ \text { 3f } & \mathrm{Cl} & \mathrm{H} & \mathrm{H} & \mathrm{H} & \mathrm{H} & 1 \\ \text { 3g } & \mathrm{Cl} & \mathrm{OMe} & \mathrm{F} & \mathrm{F} & \mathrm{H} & 2 \\ \text { 3h } & \mathrm{Cl} & \mathrm{OMe} & \mathrm{F} & \mathrm{F} & \mathrm{H} & 1\end{array}$

$\begin{array}{llllll}\mathbf{X} & \mathbf{Y}_{2} & \mathbf{Y}_{3} & \mathbf{Y}_{4} & \mathbf{Y}_{3} & \mathbf{n}\end{array}$ 4a $\begin{array}{llllll}\mathrm{Me} & \mathrm{F} & \mathrm{H} & \mathrm{H} & \mathrm{H} & 2\end{array}$ $\begin{array}{lllllll}4 b & \mathrm{Me} & \mathrm{H} & \mathrm{H} & \mathrm{F} & \mathrm{H} & 2\end{array}$ $\begin{array}{lllllll}4 \mathrm{c} & \mathrm{Me} & \mathrm{F} & \mathrm{H} & \mathrm{H} & \mathrm{H} & 1\end{array}$ $\begin{array}{lllllll}4 d & M e & H & H & F & H & 1\end{array}$ $\begin{array}{lllllll}4 \text { e } & \mathrm{Me} & \mathrm{H} & \mathrm{H} & \mathrm{H} & \mathrm{H} & 2\end{array}$ $\begin{array}{lllllll}4 f & \mathrm{Me} & \mathrm{H} & \mathrm{H} & \mathrm{H} & \mathrm{H} & 1\end{array}$ 4g $\begin{array}{llllll}M e & F & F & F & H & 2\end{array}$ 671 


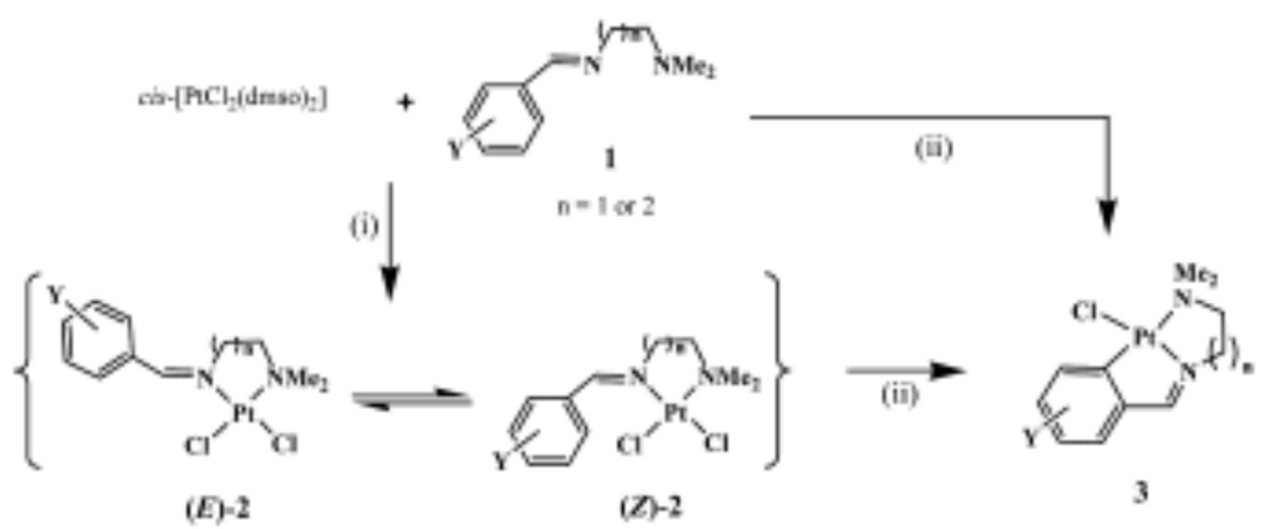

675

676

677

678 


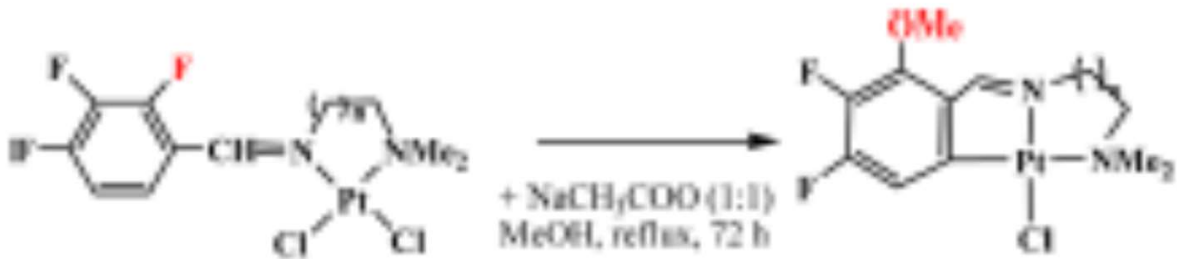

3g: $n=2$

683 


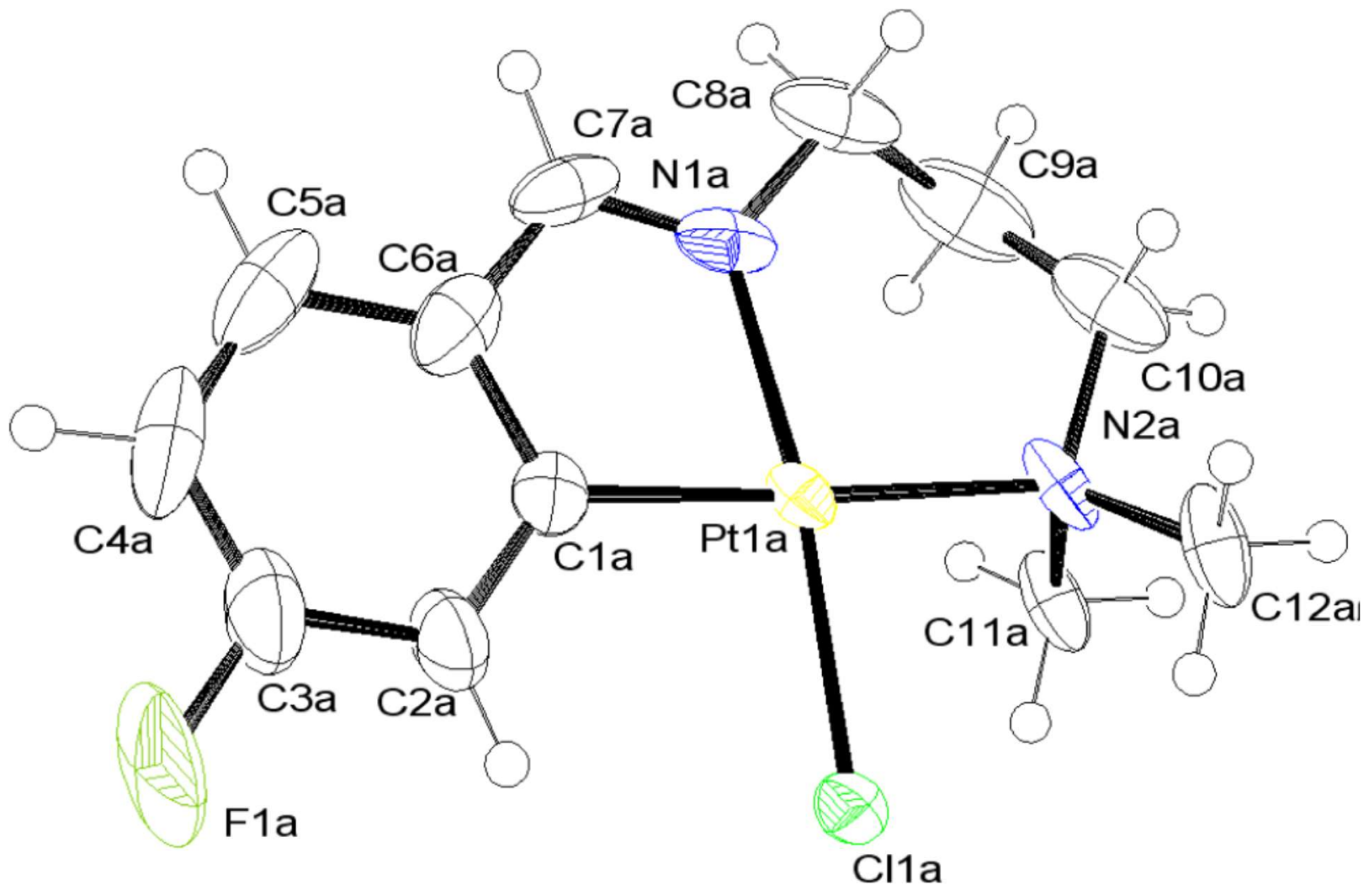

687 
689

690

691

FIGURE 2

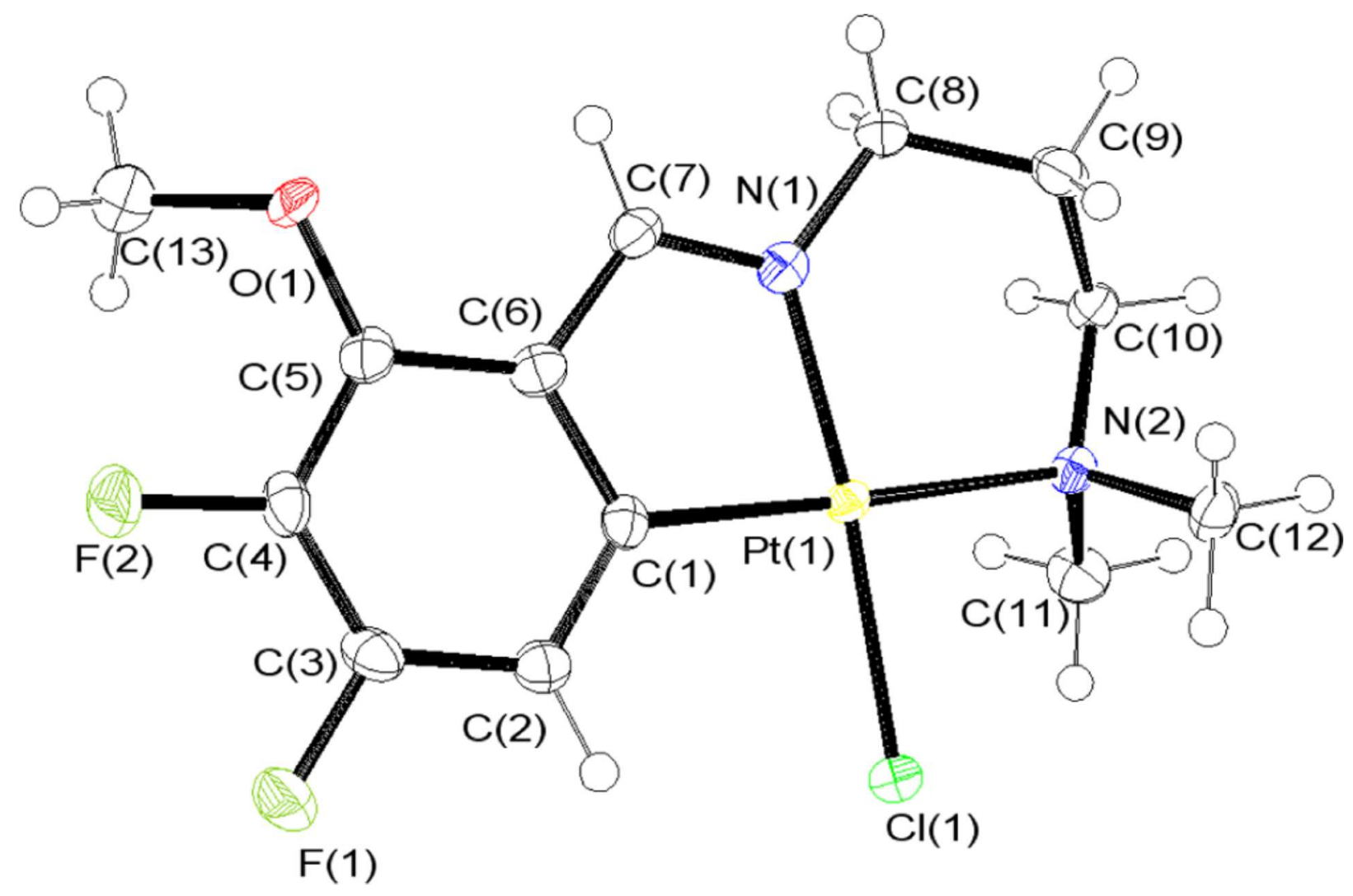

692

693

694 


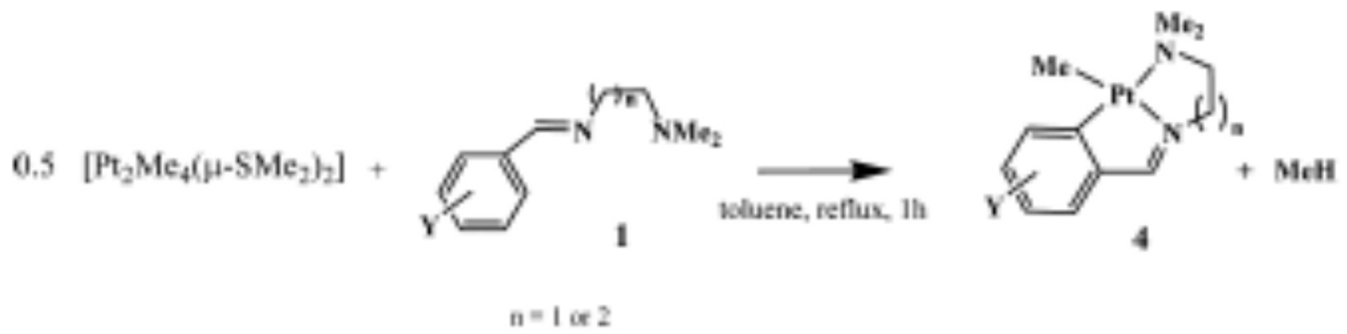

698

699 


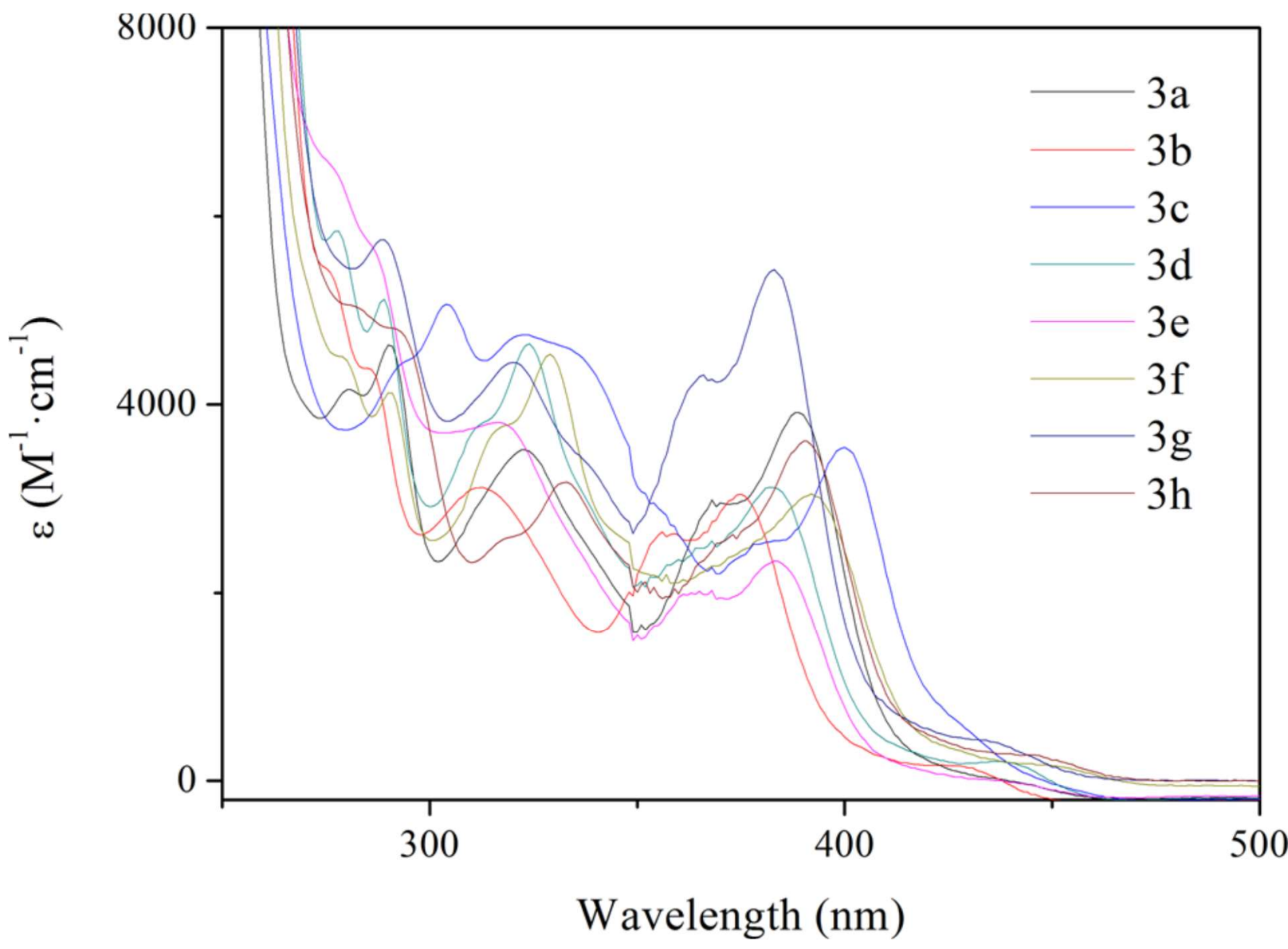




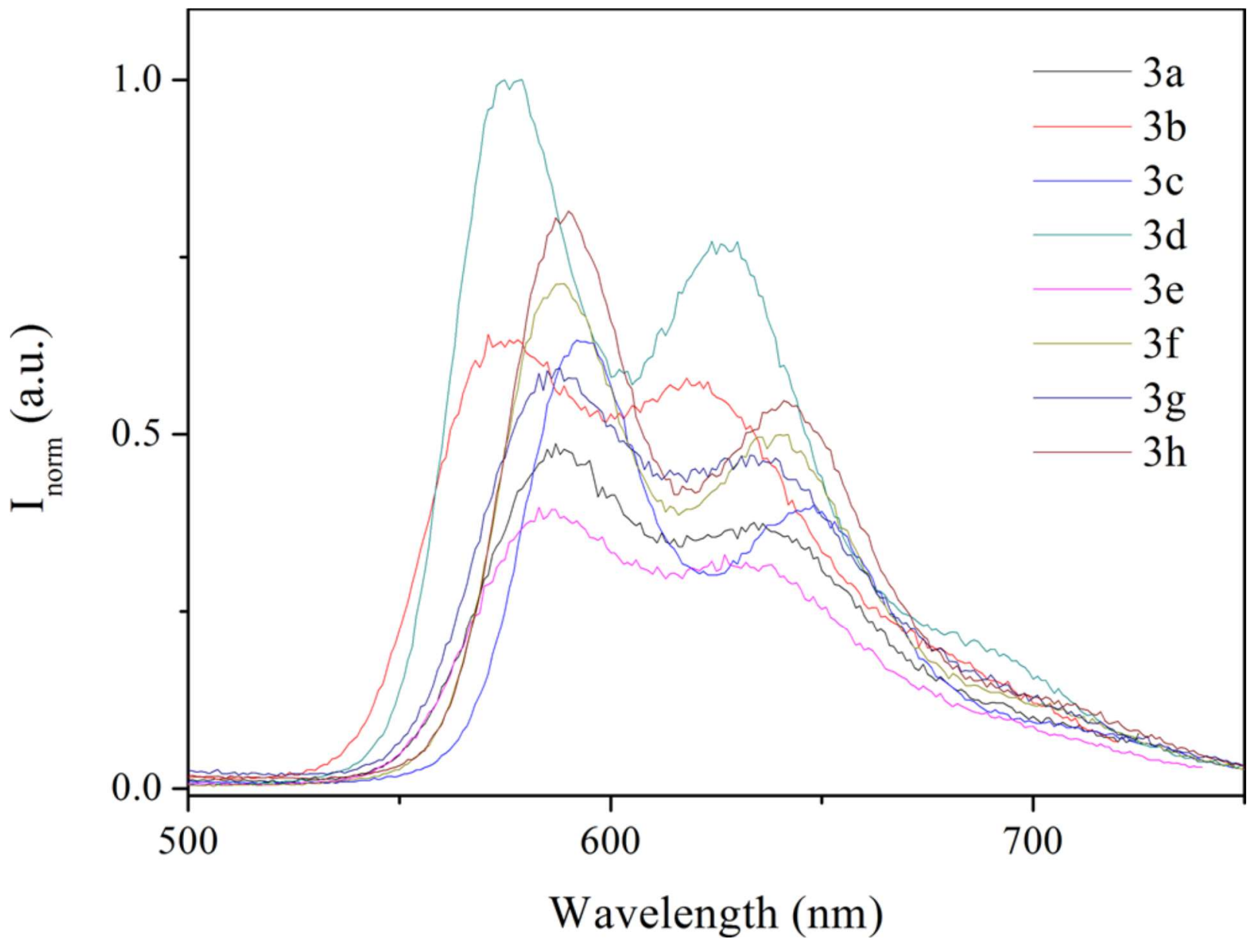




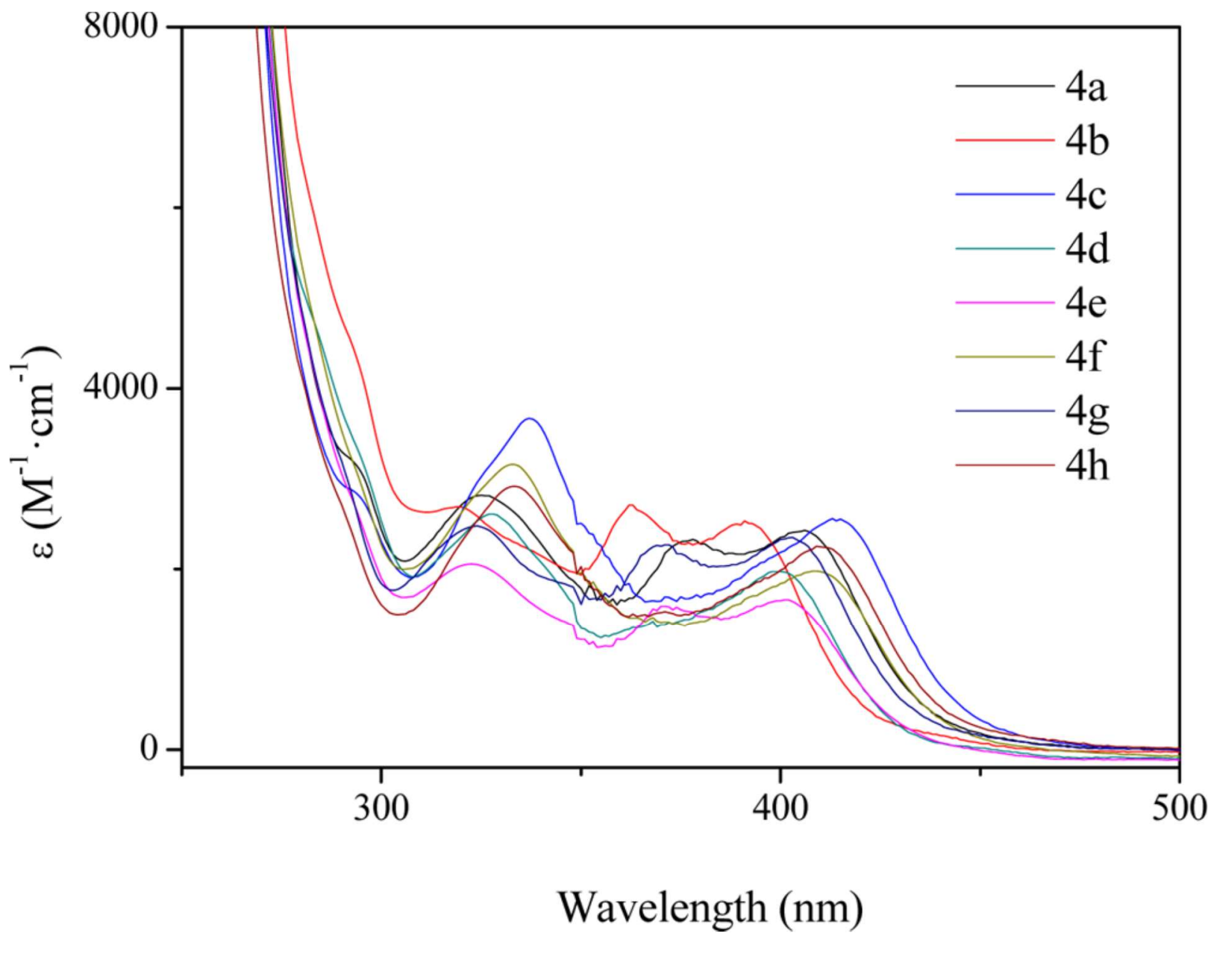




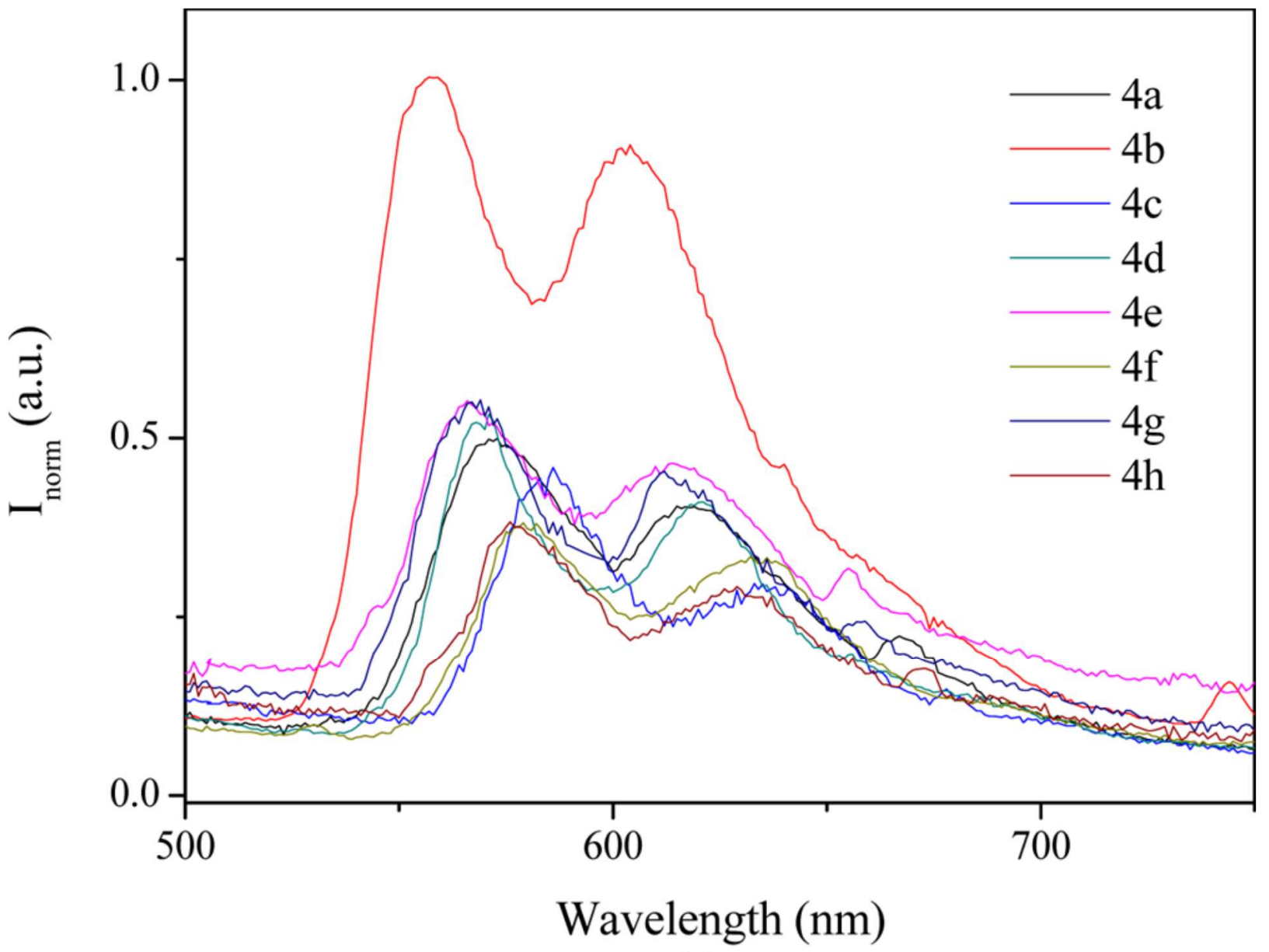


720 Table 1. Absorption and Emission Properties of Cyclometalated Platinum Compounds 3 and 4 in $721 \mathrm{CH} 2 \mathrm{Cl} 2$ Solution and in the Solid Statea

\begin{tabular}{|c|c|c|c|c|c|}
\hline complex & Lbsorption $\lambda_{\text {sed }} / \operatorname{mm}\left(\alpha / \mathrm{M}^{-1} \mathrm{~cm}^{-1}\right)$ & enkibion in solution $\lambda_{-a} / \mathrm{am}$ & embedion in solid $\lambda_{-2} / \mathrm{nm}$ & $\phi^{l}$ & $\tan / K$ \\
\hline 3a & $290(4631), 323(3517), 388$ (3914) & $358,639,707$ & $589,641,710$ & 00025 & 298 \\
\hline 3b & $311(3114), 376(3022)$ & $577,622,650$ & $575,616,675$ & apo3s & 298 \\
\hline $3 c$ & $304(4917), 330(4513), 400(3439)$ & $593,644,715$ & $595,644,712$ & 00028 & 298 \\
\hline 3d & $327(3570), 381(2753)$ & $575,624,690$ & $567,616,678$ & 00048 & 298 \\
\hline $3 e$ & $316(3663), 383(2250)$ & $586,633,701$ & $577,625,690$ & 00032 & 298 \\
\hline $3 f$ & $329(4359), 391$ (2911) & S88, 641,704 & $580,639,702$ & 00036 & 298 \\
\hline $3 g$ & $323(4155), 383(5074)$ & $590,642,698$ & $590,642,702$ & 00028 & 298 \\
\hline $3 \mathrm{~h}$ & $332(3250), 391$ (3701) & 590,634700 & $575,625,690$ & 00035 & 298 \\
\hline $4 a$ & $325(2734), 378(2283), 408(2324)$ & $575,619,673$ & $586,630,650$ & $<$ & 77 \\
\hline $4 b$ & $319(2446), 362(2464), 391(2298)$ & $557,604,664$ & $573,618,658$ & $c$ & 77 \\
\hline $4 c$ & $337(3240), 415(2287)$ & $585,637,685$ & $589,649,650$ & $<$ & 77 \\
\hline $4 d$ & $328(2462), 399$ (1853) & $568,621,681$ & $569,619,678$ & 6 & 77 \\
\hline $4 e$ & $322(2053), 401(1657)$ & $566,615,665$ & $585,632,679$ & $<$ & 77 \\
\hline $4 i$ & $332(2956), 408(1876)$ & $580,634,685$ & $583,639,685$ & 6 & 77 \\
\hline 48 & $324(2343), 372(2145), 403(2222)$ & $567,620,675$ & $587,630,650$ & $<$ & 77 \\
\hline 4h & $333(3053), 409(2359)$ & $578,633,684$ & $580,634,659$ & $<$ & 77 \\
\hline
\end{tabular}

${ }^{a}$ Emission spectra were recorded upon exdation at the lowest enengy absorption band. ${ }^{b} \mathrm{Qu}$ antum yields for emiscion in solution referred to $\left[\mathrm{Ru}(\mathrm{bipy})_{3}\right] \mathrm{Cl}_{2}$ in $\mathrm{H}_{2} \mathrm{O}$. Sot ohrerved. 